\title{
Characteristics of electrical energy storage technologies and their applications in buildings
}

\author{
Aikaterini Chatzivasileiadi, Eleni Ampatzi, lan Knight \\ Welsh School of Architecture, Cardiff University, Bute Building, \\ King Edward VII Avenue, Cardiff CF10 3NB, Wales, United Kingdom \\ e-mail: ChatzivasileiadiA@cardiff.ac.uk,AmpatziE@cardiff.ac.uk, \\ Knight@cardiff.ac.uk \\ Corresponding author: Aikaterini Chatzivasileiadi
}

Tel: +44 (0) 29 20875496, Fax: +44 (0) 2920874623

\begin{abstract}
This study has been undertaken to gain a better understanding of how to allow for energy storage in the design of a future built environment where renewable energy systems will play a significant role.

Electricity storage solutions are a key element in achieving high renewable energy penetration in the built environment. This paper presents an overview of electricity storage technologies and their distinct characteristics. The currently available technologies have been classified according to the means by which each can be used in supplying energy to buildings.

As the storage market is evolving rapidly, the analysis provides an up-to-date evaluation of different storage options with regard to scale, reliability and sitespecificity among others.

It is concluded that Li-ion batteries, which today have a limited use in the built environment, and Zn-air batteries that will be commercialized in 2013/14 are amongst the most promising technologies for buildings due to their exceptionally high energy density. They are expected to play an important role in reliable, economical and energy efficient building design in the future. $\mathrm{NaNiCl}$ batteries, which are currently used in vehicles, are also considered an important technology for buildings, because of their high cycle lifetime and their high peak power capability.
\end{abstract}

Keywords: Electrical energy storage; Renewable energy; Batteries; Pumped hydro; Compressed air; Flywheels

\section{Introduction}

In the last decade, increased environmental concerns have led to the formation of European energy and climate policies, which suggest a significant $\mathrm{CO}_{2}$ emissions 
reduction for the EU countries by up to $95 \%$ by 2050 is needed [1]. Towards this goal, the integration of renewable energy sources in the energy mix of the future is expected to rise (Figure 1). However, the output of many renewable energy sources, such as wind and solar, is highly variable, producing fluctuating and partly unpredictable amounts of electricity over time [2-5]. Therefore, the constant mismatch between supply and demand can have a serious impact on grid reliability and security of supply. This constitutes a new challenge, which requires the introduction of advanced energy storage solutions.

There are a number of benefits associated with the introduction of energy storage systems in the built environment. Electrical energy storage (EES) systems can contribute to increasing power systems' efficiency, as they can effectively manage the surplus electricity generation from renewable energy technologies, which would otherwise be wasted. In this way, electricity storage helps to maximize the value and the contribution of intermittent renewables $[2,6]$. Furthermore, EES systems can assist in the improvement of the electrical grid stability and reliability, as they can address the fluctuations in consumption and generation by providing the necessary flexibility [2]. In addition, EES solutions can contribute to the increase of energy security and quality of supply, by sustaining frequency and voltage at the required levels $[2,7]$. For example, electricity storage options could deal with the occurring voltage sags in case of a power failure, ensuring reliability of supply.

This paper focuses on the use of EES systems in buildings, which account for a significant share of global electricity end use and carbon emissions. Therefore, the built environment with its various uses has a high emission reduction potential and this could be achieved through a modern electricity supply system based on renewable sources and their smart management. EES systems will provide operational flexibility within a building or in the electric grid, by injecting and absorbing electrical energy to and from the grid as needed. Hence, a combination of EES systems in a variety of sizes and scales, from bulk EES installations to smaller community and local EES systems, will eventually emerge in the future built environment [8].

According to [9], there is a great potential for environmental, economic and energy diversity benefits through the use of advanced electricity storage technologies. Considering the planned large-scale introduction of renewable energy sources in the built environment in the coming years, electricity storage will play a double role. On one hand, it will enable renewable energy to be captured and stored for later use, without wasting extra amounts of resources for electricity generation; therefore, according to [9], it will be a source of efficiency. On the other hand, it can also serve as a valuable tool that will provide the needed flexibility in energy supply, by smoothing out the mismatch between supply and demand. Given the attempts currently being made towards the reduction of $\mathrm{CO}_{2}$ emissions, electrical energy 
storage technologies, along with renewable energy technologies, are expected to be a necessary element of the built environment in the future [5, 6, 9-13].

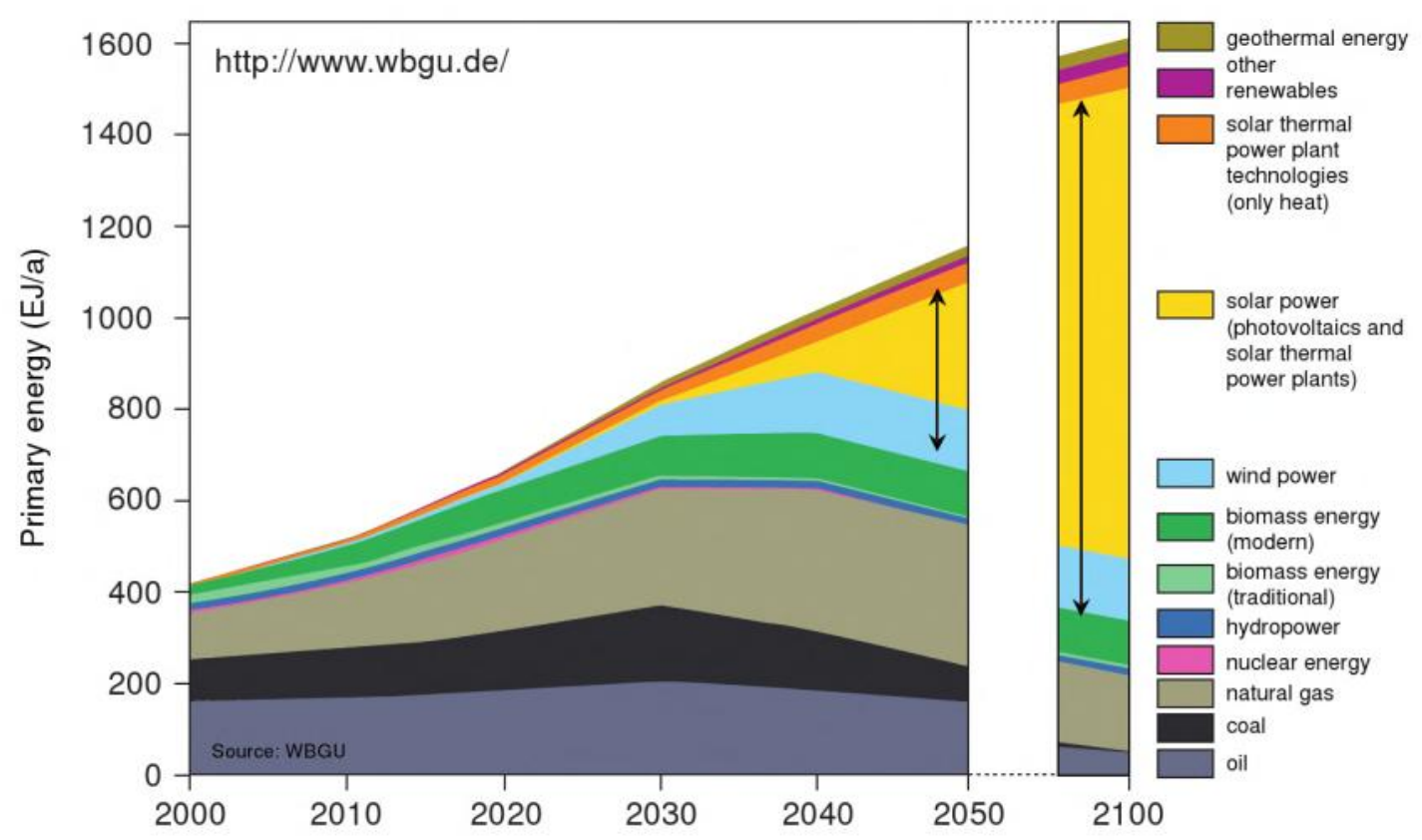

Figure 1: Scenario for a worldwide energy mix in the next decades $[11,14]$ (after the German Advisory Council on Global Change 2008)

With growing concerns about the environmental impacts of the electricity sector, the EES market is developing quite rapidly and the performance characteristics of the technologies are constantly improving. Furthermore, there are a limited number of inter-institutional collaborations in this field globally at present. Some collaborative research projects have been taking place in the US with good results $[12,15-20]$. However, a great deal of research on EES around the globe is conducted by Universities, organizations or companies independently. Hence, the aim of this study is to gather the most recent findings in the field and analyse their potential use in relation to the integration of EES systems in the built environment.

The EES technologies considered in this review are the following:

1. Superconducting magnetic energy storage (SMES),

2. Supercapacitors/electrochemical double layer capacitors (EDLCS),

3. Pumped hydroelectric storage (PHS),

4. Flywheels,

5. Compressed air energy storage (CAES),

6. Lead-acid (Pb-acid) batteries,

7. Lithium-ion (Li-ion) batteries,

8. Nickel/Cadmium (NiCd) batteries,

9. Nickel-metal-hydride (NiMH) batteries,

10. High temperature Sodium/Sulphur (NaS) batteries, 
11. High temperature Sodium nickel chloride ( $\mathrm{NaNiCl})$ batteries,

12. Zinc/Bromine $(\mathrm{ZnBr})$ batteries,

13. Redox-flow batteries,

14. Metal-air (Zn-Air) batteries, and

15. Hydrogen storage used with either a fuel cell or a gas turbine.

The functionality and operation of the EES technologies and the description of their performance parameters have been previously discussed in the literature [4, 6, 2124]. Therefore, the present paper presents an extension of the previous literature and focuses on the state-of-the-art EES technologies. It provides a comprehensive updated review of the currently available EES systems and their characteristics. The performance parameters considered in this review are the following:

1. Energy and power rating,

2. Volumetric and gravimetric energy density,

3. Volumetric and gravimetric power density,

4. Discharge time,

5. Response time,

6. Operating temperature,

7. Self-discharge rate,

8. Round-trip efficiency,

9. Critical battery voltage

10. Lifetime (in years and cycles),

11. Investment power and energy cost,

12. Spatial requirement,

13. Environmental impact,

14. Recharge time,

15. Memory effect (for rechargeable batteries),

16. Maintenance requirements,

17. Recyclability,

18. Technical maturity,

19. Transportability, and

20. Cumulative energy demand

\section{Electrical energy storage technologies}

\subsection{Classification of EES technologies}

EES technologies, according to [2, 11, 25], can be separated into two categories: "high power" and "high energy" storage systems. High power storage systems deliver energy at very high rates but typically for short times (less than 10s), while high-energy storage systems can provide energy for hours. There are also technologies that can be used either in high power or high energy systems and these 
are the electrochemical storage systems. The classification of the technologies into the above categories is shown in Table 1. In addition, with regard to the mechanisms for storing electrical energy, EES can use electrical fields, mechanical energy or chemical energy [11].

Table 1: Classification of EES systems

\begin{tabular}{|c|c|c|}
\hline $\begin{array}{l}\text { Electrical or mechanical } \\
\text { high power EES systems }\end{array}$ & $\begin{array}{c}\text { Mechanical } \\
\text { high energy EES systems }\end{array}$ & $\begin{array}{l}\text { Electrochemical EES systems } \\
\text { (HP \& HE potential)* }\end{array}$ \\
\hline $\begin{array}{l}\text { Superconductive magnetic } \\
\text { energy storage (SMES) }\end{array}$ & $\begin{array}{l}\text { Compressed air energy } \\
\text { storage (CAES) }\end{array}$ & $\begin{array}{l}\text { Accumulators with internal } \\
\text { storage (e.g. } \mathrm{Pb} / \mathrm{PbO}_{2}, \mathrm{NiCd} \text {, } \\
\text { Li-ion, } \mathrm{NiMH}, \mathrm{NaNiCl}, \mathrm{NaS} \text { ) }\end{array}$ \\
\hline $\begin{array}{l}\text { Supercapacitors/ } \\
\text { Electrochemical double layer } \\
\text { capacitors (EDLCs) }\end{array}$ & \multirow[t]{2}{*}{$\begin{array}{l}\text { Pumped hydro energy } \\
\text { storage (PHS) }\end{array}$} & \multirow{2}{*}{$\begin{array}{l}\text { Accumulators with external } \\
\text { storage (e.g. hydrogen } \\
\text { storage system, flow } \\
\text { batteries) }\end{array}$} \\
\hline Flywheels & & \\
\hline
\end{tabular}

*Electrochemical EES systems can be used either in high power (HP) or high energy (HE) applications

For example, as Table 1 shows, SMES, EDLCs/supercapacitors, and flywheels are suitable for high power and short duration applications, providing power quality and grid stability. SMES and EDLCs use electromagnetic and electrostatic energy correspondingly to store the available electrical energy, while flywheels use rotational energy, which is a form of mechanical energy. On the other hand, CAES and pumped hydro energy storage systems are suitable for high energy applications, providing load leveling and seasonal storage improving the reliability of the grid. These systems convert electrical energy to and from mechanical energy. High power or high energy electrochemical storage systems store chemical energy, which is then converted back to electricity when needed.

As [11] argues, the requirements concerning power, energy and discharge times are very different and are presented in Figure 2, taken from the International Electrotechnical Commission's white paper on electrical energy storage [26]. Figure 2 comprises not only the application areas of today's EES systems but also the predicted range in future applications. For example, the world's two CAES plants currently in operation are installed in Germany and the USA and have a power rating of $290 \mathrm{MW}$ and $110 \mathrm{MW}$ respectively $[11,26]$. However, according to the International Electrotechnical Commission, CAES applications' rated power is projected to exceed $500 \mathrm{MW}$, so systems of this power are expected to be installed in the future [26]. In addition, the Li-ion battery project of $12 \mathrm{MW}$ in Chile was the largest of its kind when it was built in 2009 [27]. The system could feed the grid with electricity at this power for 20 minutes [26]. In 2011 a much bigger Li-ion installation 
of $32 \mathrm{MW}$ that is able to deliver its rated power for 15 minutes was realized in West Virginia, USA [27]. Hopefully, as Figure 2 suggests, the range of Li-ion applications' power, energy and discharge time values will be expanded even further in future applications, i.e. up to $50 \mathrm{MW} / 50 \mathrm{MWh}$.

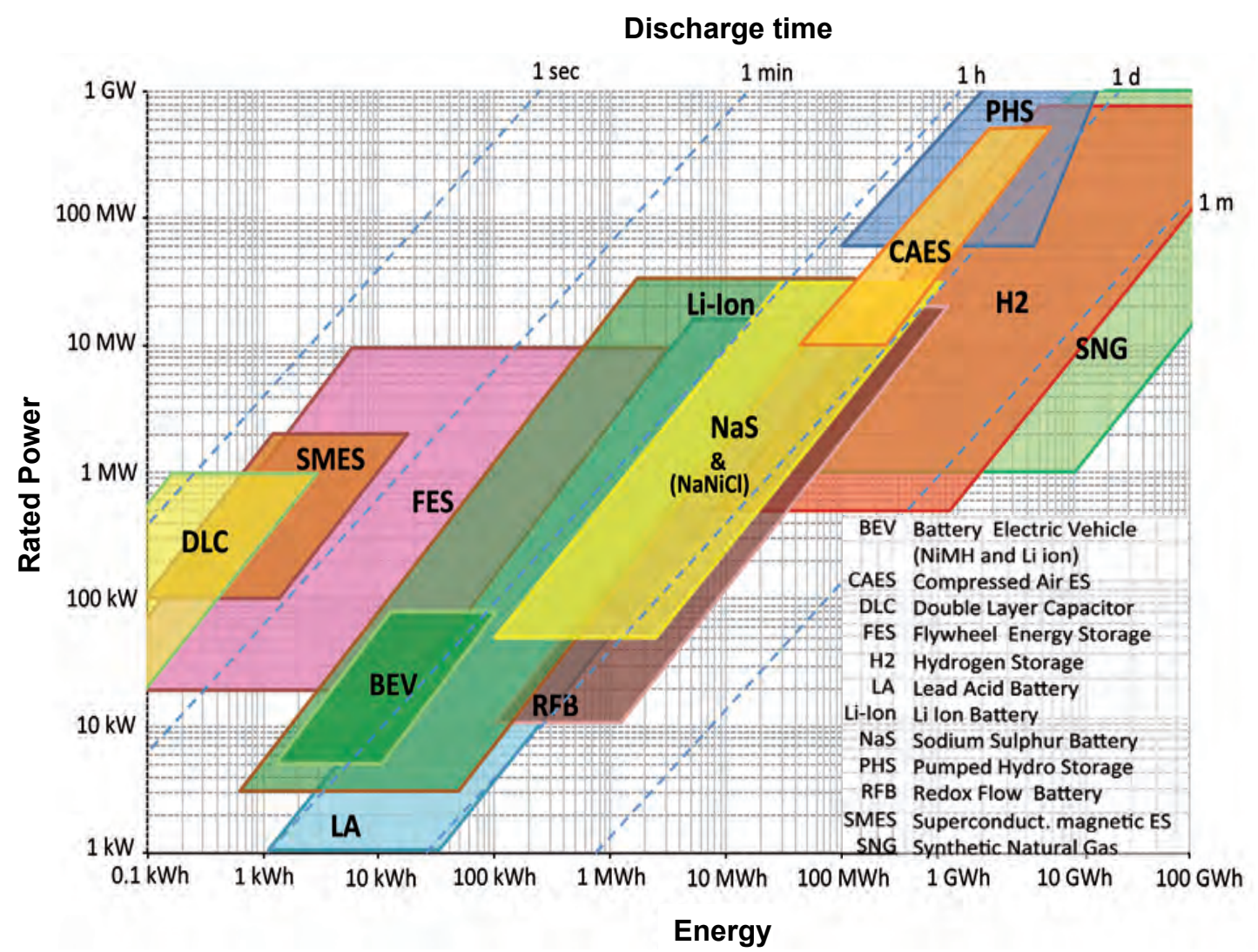

Figure 2: Comparison of rated power, energy content and discharge time of different EES technologies [26] (after Schwunk 2011)

The currently available types of EES technologies exhibit a large spectrum of performances and capacities to match different application environments and electricity storage scales. Not all EES systems are commercially available in the ranges shown at present, but according to [26] all are expected to become important. Moreover, most of the technologies could be implemented with even larger power output and energy capacity, as all systems have a modular design. The general up-to-date characteristics of each technology along with relevant international experience from case studies and demonstration projects are given below. The technologies of high power are presented first, those of high energy second and then follow the electrochemical storage systems.

\subsection{High power EES technologies}

\subsubsection{Superconducting Magnetic Storage Systems (SMES)}


This technology has installed capacities of up to about 10MW and is most commonly used for power quality improvement. According to [3, 22], so-called micro-SMES devices in the range of 1-10 MW are commercially available and as [11] observes, they are used in a number of technical applications where very high magnetic fields are required, such as in medical devices. It should be noted that SMES cannot be currently used as high power storage systems for grid-scale storage. Issues related to the complexity, the efficiency, the high cost and environmental impact of the system have hindered the widespread deployment of this technology [4, 9, 11]. However, such facilities have been used in a test bed project in northern Wisconsin to provide grid stability $[3,4,9]$. The system consists of six or seven units rated at $3 \mathrm{MW}$ power/0.83 kWh energy and is the largest SMES installation so far $[28,29]$.

\subsubsection{Supercapacitors /Electrochemical double-layer capacitors (EDLCS)}

These systems would be more suitable for applications with many charge and discharge cycles and discharge times around 10 seconds [11]. EDLCs can be used in various applications, but are particularly common in energy smoothing and momentary-load devices. For example, they serve as efficient battery packs in vehicles, in wireless communications or in mobile computing [30]. According to [31], they are also used in industrial applications (e.g. electronic door locks) or smaller installations like home solar energy systems where very fast charging is sometimes required. Furthermore, they can be used in combination with battery storage in uninterruptible power supplies (UPS) and similar applications. Such hybrid storage facilities provide the flexibility to use the most appropriate system between the two according to the duration of the interruption. On this occasion, EDLCs can deal with short interruptions, while the batteries are required to handle only long interruptions. For example, EDLCs would operate in the cases that interruptions are in the order of milliseconds or seconds, while batteries would only be used when disruptions in the range of minutes to hours occur. This results in the reduction of the batteries' cycling duty and the extension of their lifetime [10, 13, 32].

In addition, a new storage technology for grid-scale energy storage was recently developed by researchers from Drexel University [33]. It is an "electrochemical flow capacitor" and it stores energy in the same way as a supercapacitor. This promising technology is said to be fast, efficient and less costly to scale up for large, industrial applications.

\subsubsection{Flywheels}

These are typical high power storage systems and are used in applications that intersect the areas of capacitors and batteries for provision of power over $80 \mathrm{~kW}$ over a period of 1 to 100 seconds [30]. They are suitable for use in uninterrupted 
power supply systems (such as those in large data centres) for ride-through power necessary during transfer, as well as in electric vehicle applications (buses, trams, rail, subways) and in lifting devices (e.g. container terminals in harbours). They can also be used for grid energy storage for frequency regulation [11]. For example, Beacon Power's flywheel energy storage plant in New York aims to use 200 flywheels networked together to store excess energy from the grid and dispense it when needed [34]. In addition, this technology has already been operating in remote highpenetration systems in Australia, Antarctica and Europe improving power quality [35]. The islands of la Graciosa and Flores in the Azores and the Coral Bay in Western Australia among others are relevant case studies [36].

\subsection{High energy EES technologies}

\subsubsection{Compressed air energy storage (CAES)}

They are used to store energy during periods of low demand and release the stored energy during periods of high demand (i.e. load-shifting). These systems are a mature storage technology for high-power, long-term load-leveling applications, which is suited to build storage systems in the range of several 100MWh or more [11]. There are currently two large CAES systems installed worldwide, which are used for peak leveling on a daily basis. The first is in Huntdorf, Germany with a discharge power of 290MW and the other one in Alabama, USA with a discharge power of $110 \mathrm{MW}[11,25,30,37]$. The CAES plant in Huntorf has a roundtrip efficiency of approximately $41 \%$, while the CAES plant in Alabama has a higher efficiency of $54 \%$ [26].

In addition to large-scale facilities, CAES can also be adapted for use in distributed, small-scale operations [38]. However, technological and financial risks have prevented the demonstration of CAES at distribution level, although the technology is well understood [2]. More specifically, further technology development needs to take place for the efficient operation of the compressor and the heat capture system, as well as for the optimisation of air turbines and expanders. Furthermore, the investigation for advanced materials for pressure vessels is identified as a research need for the greater deployment of CAES in decentralised applications [39]. As regards the financial obstacles, the investment costs remain high and the decentralised small-scale CAES installations have considerably higher operation and maintenance costs than large-scale CAES systems [38, 39].

Decentralised small-scale CAES systems could form a cluster of dispersed installations and potentially serve as Virtual Power Plants (VPPs) at the distribution level, being collectively controlled by a central unit. Their interconnection would provide higher efficiency and flexibility. In addition, distributed CAES systems could be of use in places that are not easily accessible, but have ample renewable energy 
resources for electricity generation. According to [39], several companies are working towards increasing the technical maturity of small CAES and the commissioning of the first distributed CAES pilot plants is expected to occur in late 2013. Generally the economic viability of CAES is questionable at present, as these systems are currently used only for single applications. Therefore, if CAES systems are capable of addressing different markets simultaneously in the future, they will prove their economic viability and make a good business case for energy storage [39].

With regard to small scale CAES, a 'compressed air battery' was recently developed in the United Kingdom [39, 40]. Each module of this new technology can have a power rating of up to $200 \mathrm{~kW}$ and it can provide scalable solutions of a power rating in the MW scale. According to the UK company Pnu-Power who developed the technology, compressed air batteries can be used in UPS and standby power applications and are already being used by the UK and USA National Grids [40]. It can thus be an efficient flywheel or battery alternative for such applications. The roundtrip efficiency of such systems is over $80 \%$ [39] and they are highly reliable [40]. They are also claimed to have low investment and running costs, low maintenance requirements, fast installation and very low environmental impact [40].

\subsubsection{Pumped-hydro energy storage (PHS)}

This is the oldest kind of large-scale energy storage being used since the 1890's and currently accounts for $95 \%$ of the global storage capacity [32]. These systems have installed capacities in the GW range and are typically used for load leveling on a daily basis [11]. Exhibiting a rapid response speed (1/2-3mins), they also serve as an emergency reserve in case of sudden changes in demand or sudden shutdowns of power plants [41]. The construction time for such systems is usually over 10 years $[11,42]$. Some examples of pumped-hydro energy storage, according to [11, 29, 42], are the Dinorwig storage system in North Wales, the Tianhuangping plant in China and a plant in Thuringia, Germany, which is the newest one. The plant in Dinorwig runs on average at 74-75\% efficiency, has an installed power capacity of 1,650 MW and can provide power for up to 6 hours before running out of water [43]. The Tianhuangping pumped storage hydroelectric project according to [44] is the biggest of its kind in Asia. It has a total installed capacity of 1,800 MW and an overall cycle efficiency of $70 \%$. The two pump storage reservoirs of this system have a difference in elevation of $590 \mathrm{~m}$ and both have a storage volume of 8 million $\mathrm{m}^{3}$. Tianhuangping plant's mean annual output is $30.14 \times 10^{2} \mathrm{GWh}$ [44]. The pumped hydro system located on Thuringia has a power capacity of $1 \mathrm{GW}$ and can provide energy at this rate for 8 hours, thus $8 \mathrm{GWh}$ [11]. 


\subsection{Electrochemical storage systems}

These are classified into two groups; systems with integrated energy storage (e.g. lead-acid batteries, NiCd batteries, NiMH batteries, Li-ion batteries, NaS batteries, $\mathrm{NaNiCl} / Z$ EBRA batteries) and systems with external energy storage (e.g. V-redox, $\mathrm{ZnBr}, \mathrm{Zn}$-air batteries, hydrogen storage systems). In systems with external energy storage, there is a physical separation between the energy conversion unit and the charged active material, while in systems with integrated energy storage the charge/discharge reaction takes place directly in the active material, so no spatial separation occurs on this occasion. Systems with external storage are capable of being independently sized for power and energy for the storage facility, whereas in systems with integrated storage the available charge/discharge power is always relative to the energy storage capacity [11].

According to [38], the battery technologies that can be used for large-scale energy storage in stationary applications and are commercially available today are lead-acid, $\mathrm{NiCd}$ and $\mathrm{ZnBr}$ batteries. However attempts have recently been made to use stationary Li-ion batteries in utility scale. As an example, a $12 \mathrm{MW} / 3 \mathrm{MWh}$ Li-ion battery was installed in Chile in 2009 [26]. The battery serves for frequency regulation and contributes to the efficient management of fluctuations in demand.

The power rating of a large battery system would usually be in the range of $100 \mathrm{~kW}$ $10 \mathrm{MW}$, and the battery would be used to provide balancing services in the electric grid [45]. The largest stationary NiCd battery operates in Alaska, USA, as a local backup system $[11,37,38]$. NaS batteries have the potential to be used in bulk energy storage as well as for load-leveling purposes. An example highlighting this potential is the use of the NaS energy storage technology in the island of Graciosa in the Canary Islands, where a stand-alone renewable energy network is currently being developed [46]. As regards the EES facilities on the island, two $500 \mathrm{~kW} \mathrm{NaS}$ battery units have been installed for large-scale storage.

With respect to the battery technologies that can be applied to distributed generation, these are lead-acid, $\mathrm{NaS}, \mathrm{NiCd}$, Li-ion, $\mathrm{ZnBr}$ and redox-flow batteries. Metal-air rechargeable batteries and especially $\mathrm{Zn}$-Air, which are a very promising technology, are currently under development. They have the potential to be used not only in distributed applications, but also in utility-scale energy storage and are expected to be commercially available in 2013/2014 [47, 48]. Hydrogen storage used with either a hydrogen fuel cell or hydrogen gas turbine is also available for distributed energy storage [38].

As [49] observes, none of the currently available battery technologies can meet the demanding performance requirements of the grid, which are very high power, long lifetime and very low cost. A recent innovation was inspired by Sadoway, who is working on a grid-size battery system that stores energy using a three-layer liquid- 
metal core. It is a high temperature $\mathrm{Mg} / \mathrm{Sb}$ battery technology and is said to be inexpensive, robust and incredibly efficient.

It is apparent that some technologies have a few overlapping characteristics regarding their applications, but on the whole they are very distinct from each other. The parameters explained above along with others have been gathered in a comprehensive table, including information for each of the EES technologies discussed in this study. Therefore, Table 2 is the main outcome of this study and includes the most important characteristics of EES technologies. 
Table 2: Characteristics of EES technologies (References for each cell are provided at the end of the paper).

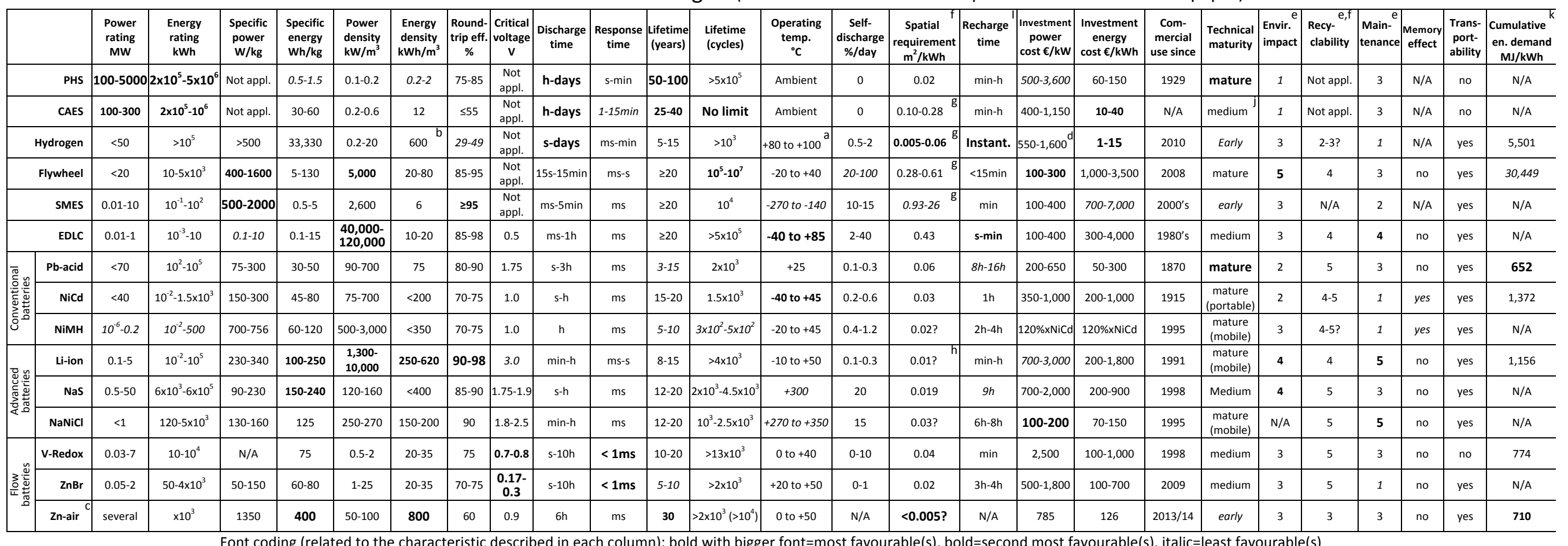

Font coding (related to the characteristic described in each column): bold with bigger font=most favourable(s), bold=second most favourable(s), italic=least favourable(s)

Notes for Table 2:

a. Hydrogen's operating temperature of $80-100^{\circ} \mathrm{C}$ relates to polymer electrolyte fuel cells. The operating temperature of solid electrolyte fuel cells is $1000^{\circ} \mathrm{C}$ [11].

b. Hydrogen's energy density of $600 \mathrm{kWh} / \mathrm{m}^{3}$ is for a pressure of 200 bar.

c. Zn-air energy storage system refers to rechargeable flow battery technology; it is an emerging technology, which has been developed very recently

d. The power price reported for hydrogen relates to gas turbine based generator. The power price for fuel cells is in range of 2,000-6,600 $€ / \mathrm{kW}[10]$.

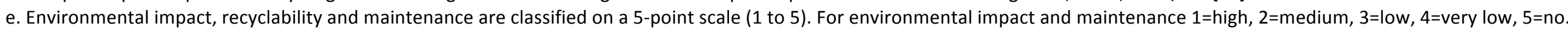

For recyclability $1=$ poor, $5=$ excellent.

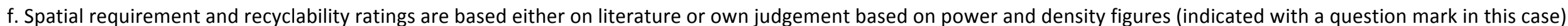

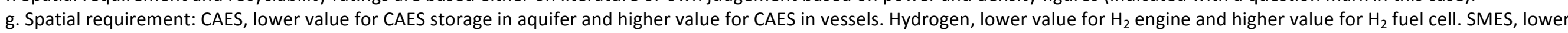
value accounts for large SMES and higher value accounts for micro-SMES. Flywheels, low value for high-speed flywheels and higher value for low-speed flywheels.

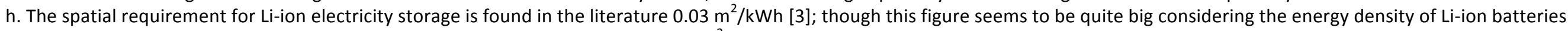
currently found in the literature [32], so an adjustment on this figure is made $\left(0.01 \mathrm{~m}^{2} / \mathrm{kWh}\right)$.

i. The recharge time for each technology is proportionate to the size of the system.

j. Technical maturity: diabatic CAES storage according to [26] is a mature technology, while adiabatic CAES is at an early development stage.

k. Cumulative energy demand: only the energy input for the material supply is included.

The hyphen in some inputs (e.g. in column energy rating) is indicative of "to". It is used as a sign to indicate the range.

$\mathrm{N} / \mathrm{A}=$ Not available in the literature, Not appl. = Not applicable 


\section{Discussion}

\subsection{Usability of Table 2}

Comparisons among the EES technologies and their characteristics are facilitated through the use of Table 2 above. For instance, let us assume that an architect is asked to integrate an electricity storage system in a remote building in the Mediterranean, powered by photovoltaics. The system would serve as electricity reserve for the building and the priority that the owner has set for the system is maximum efficiency.

The application described in the example is a high-energy application, so, according to Table 2, maximum efficiency is provided by either $\mathrm{Li}$-ion or $\mathrm{NaNiCl}$ batteries at present, with Li-ion scoring a bit higher. For convenience, Li-ion and $\mathrm{NaNiCl}$ rows of Table 2 are highlighted in Figure 3.

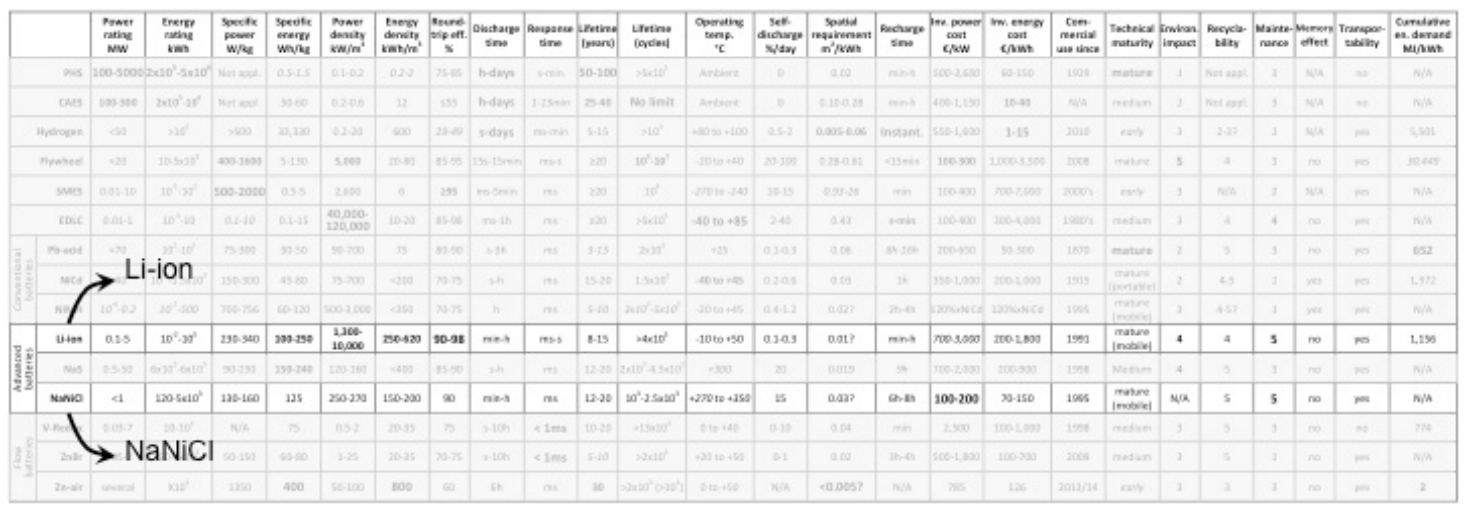

Figure 3: Li-ion and $\mathrm{NaNiCl}$ technologies as most favourable ones for the case example

Li-ion batteries have a considerably higher energy density (indicated in bold) than $\mathrm{NaNiCl}$ batteries, which results to a lower spatial requirement in the area that the building occupies. This may not be an issue in this case under the specific assumptions, as there will possibly be enough space to accommodate either of the two systems; the lifetime and the maintenance requirements though may need to be considered, as the building is located in a remote area. $\mathrm{NaNiCl}$ batteries may be a better option in this respect, as they can last up to 20 years, while Li-ion batteries are unlikely to exceed 15 years. Hence, the replacement time will luckily be higher for the $\mathrm{NaNiCl}$. Regarding maintenance, both technologies score high, so the occupants will not have to bother about calling a technician for this purpose or about the associated costs. In addition, the response and discharge times will be pretty much the same for both systems, but the recharge time varies, the most favourable being Li-ion batteries'. Moreover, $\mathrm{NaNiCl}$ batteries have a quite high self-discharge per day (losses due to heating), which could cause inconvenience to the occupants depending on the battery's frequency of use. 
$\mathrm{Li}$-ion batteries seem to have a lead over $\mathrm{NaNiCl}$ systems so far. However, there are huge differences on the investment costs of these two technologies. Li-ion is far more expensive than $\mathrm{NaNiCl}$, which is a point that would perhaps be of interest to the owner. In this instance, the power costs for $\mathrm{Li}$-ion and $\mathrm{NaNiCl}$ are indicated in italic and bold correspondingly. Furthermore, the recyclability rating is somewhat higher for $\mathrm{NaNiCl}$, which would maybe affect the decision of an environmentally conscious owner.

As a matter of fact, an analysis provided by [26] regarding a similar scenario suggests that $\mathrm{Li}$-ion and $\mathrm{NaNiCl}$ batteries would be appropriate storage solutions for the building powered by photovoltaics, which confirms the findings based on Table 2 . The limitation that is presented for $\mathrm{NaNiCl}$ is the cycling on a daily basis so that additional heating is avoided, while for the Li-ion the investment costs consist a concern [26].

The interpretation described above, which is based on the information provided in Table 2, shows that it is unlikely that a storage technology scores high in all parameters. Moreover, it is not possible to state univocally that a certain (battery) storage technology is better, while the other is not. Each case is unique and depending on the application and the corresponding parameters, the final decision can vary. In any case, the decision making process towards the most favourable option is a compromising process.

\subsection{Opportunities for integration of EES technologies in the built environment}

The previous sections have shown that there are many options for storing electrical energy. It is a fact though that no single storage technology can fulfill all requirements; yet, as [11] observes, there are storage technologies available for any level of renewable energy penetration. Therefore, the preferred storage solution is best chosen depending on the application requirements such as energy and power density, discharge time, user profile and others.

Pumped-hydro (PHS), CAES systems and hydrogen are the only storage technologies available for high power and energy capacities and are suitable for large-scale energy storage, although energy density is rather low for PHS and CAES. Pumped-hydro energy storage systems are the only currently feasible large-capacity storage technology for long discharge times ( $>1$ day) and will remain the most efficient technology, while CAES need to be developed further [26]. In addition, PHS and CAES are dependent on suitable geographical locations, which are generally topographically limited.

Among the large-scale solutions, hydrogen provides the highest possible energy density and enables storage capacities of over 100GWh [7, 26]. Hydrogen storage used with either a fuel cell or gas turbine can currently contribute to distributed generation and exhibits the longest discharge time, i.e. days to months. For discharge 
times of days to months, according to [26], no electrical energy storage technology has so far been put into practical operation. In this respect, the development of new storage technologies such as hydrogen is considered to have a high potential. The technologies suitable for applications with medium discharge time, i.e. minutes to hours, are mainly electrochemical EES, such as lead-acid, Li-ion and NaS batteries. Flywheels have also been reported to be suitable for such applications [26]. PHS, CAES and V-redox batteries are situated between storage systems for medium discharge times and hydrogen storage. All high power storage technologies such as EDLCs, SMES and flywheels are suitable for applications with short discharge times.

Requirements for up to approximately $10 \mathrm{MW}$ for maximum 6-8 hours can be addressed by battery type solutions [38]. Lead-acid, $\mathrm{NiCd}$ and $\mathrm{ZnBr}$ batteries could be used for either bulk energy storage or distributed generation. $\mathrm{Li}$-ion, $\mathrm{NaS} / \mathrm{NaNiCl}$ and redox-flow batteries are mainly suited to distributed energy storage applications, while NaS battery storage has the potential to be used in large-scale energy storage as well. The available energy storage technologies for power quality applications at present are lead-acid batteries, NaS batteries, flywheels, SMES and supercapacitors/EDLCs, while Li-ion batteries also seem to be a promising technology for such applications [13].

$\mathrm{Zn}$-air is the technology with the best gravimetric and volumetric energy density, which means that they are the lightest option and occupy the least space [50]. Li-ion batteries are also a very good option in this respect, while PHS systems are the least favourable option. Among high-power technologies, SMES systems have the highest specific power of 500-2,000W/kg, while EDLCs exhibit an exceptionally high power density in the range of $40,000-120,000 \mathrm{~kW} / \mathrm{m}^{3}$. Both of these technologies have very fast response times too, which are in the range of $\mathrm{ms}$ (milliseconds). Flywheels and $\mathrm{Li}$-ion batteries also have competitive power density values, while $\mathrm{V}$-redox and $\mathrm{ZnBr}$ batteries have the best response time, which is less than $1 \mathrm{~ms}$.

EDLCs can operate over a wide temperature range of $-45^{\circ} \mathrm{C}$ to $85^{\circ} \mathrm{C}$ and in various environments, such as hot, cold or moist. The $\mathrm{NaNiCl}$ battery which is a high temperature technology, also has a broad temperature range of $-40^{\circ} \mathrm{C}$ to $70^{\circ} \mathrm{C}$. $\mathrm{NiCd}$ batteries, like $\mathrm{NaNiCl}$, are capable of performing well even at low temperatures reaching $-40^{\circ} \mathrm{C}$. Lead-acid batteries typically operate at about $27^{\circ} \mathrm{C}$, but a change of $5^{\circ} \mathrm{C}$ or more can reduce the life of the battery by $50 \%[11,51]$. Compared to lead-acid and flow batteries, Li-ion can operate in a wider range of temperatures. SMES require extremely low temperatures, while in NaS batteries the temperature should be kept at high levels, around $300^{\circ} \mathrm{C}$. The main issue associated with such extreme temperatures (either high or low) is that a conditioning system has to be provided in order to maintain the desired temperature, which will use the storage system's own stored energy for its operation. For PHS and CAES systems, it assumed that they operate in ambient temperatures, as they are site specific and use existing land 
structures.

Flywheels and EDLCs have a very high level of self-discharge of $20-100 \%$ and $2-40 \%$ per day respectively. Flywheels' huge self-discharge rate when they are in standby mode is associated with air resistance and bearing losses. $\mathrm{NaS}, \mathrm{NaNiCl}$ and SMES systems have a considerable self-discharge rate of $10-20 \%$ per day and for $\mathrm{NaS}$ and $\mathrm{NaNiCl}$ this is attributed to the high operating temperatures that are required in order for the energy to be stored. Lead-acid and Li-ion batteries have the lowest daily self-discharge rate among all batteries of $0.1-0.3 \%$, while NiCd technology is right behind them with a range of $0.2-0.6 \%$. In addition, PHS and CAES systems have an almost negligible self-discharge rate. $\mathrm{ZnBr}$ flow batteries generally have very low selfdischarge levels too, yet they could discharge about $1 \%$ of the stored energy per hour when the pumps are running at maximum speed during standby periods [42]. What should be generally taken into consideration in energy storage planning is that the lower the self-discharge rate of a storage technology, the longer the storage period the technology is suitable for [4].

With regard to the high-energy EES technologies, PHS systems can operate at efficiencies of $75-85 \%$ and the use of adjustable speed machines in the future will result in efficiency improvements. Diabatic CAES systems currently have a limited round-trip efficiency of less than $55 \%$, however a new plant of adiabatic CAES, which is scheduled for demonstration in 2016, is expected to achieve efficiencies in the order of 70\% [26]. All high-power EES technologies, i.e. flywheels, SMES and EDLCs, are characterized by their high overall round-trip efficiency, which is in the range of $85-98 \%$. Among the electrochemical storage technologies, Li-ion batteries have the highest efficiency, which is claimed to be over $90 \%$, even reaching a $98 \%$. Hydrogen's overall efficiency is low compared to PHS and Li-ion due to the many energy conversion processes taking place, and is generally not expected to exceed $50 \%$ in current applications.

The lifetime of an EES technology can be given either in years or in cycles. PHS and CAES systems have the longest lifetimes, which are in the range of 50-100 and 25-40 years respectively as $[10,11,42]$ argue, while rechargeable batteries such as leadacid, $\mathrm{NiMH}$ and $\mathrm{ZnBr}$ have a relatively limited lifetime. However, some manufacturers claim 20 or 30 years of operating life for $\mathrm{ZnBr}$ batteries [42]. According to [26], PHS, CAES and EDLC systems have nearly unlimited cycle stability while flywheels are also a technology with a very long cycle life ranging from 100,000 to $10,000,000$ cycles. Lead-acid batteries have by far the longest cycle life of the conventional battery technologies, in the order of 2,000 cycles, but Li-ion, NaS and particularly V-redox batteries can achieve more cycles than lead-acid. $\mathrm{Zn}$-air batteries seem to be a promising technology, as their typical service life is up to 30 years. Also in terms of cycle life, they can currently achieve over 2,000 cycles and they are expected to reach a cycle life in the order of some tens of thousands in the next years [48]. 
Depending on system design there are two costs associated with EES technologies. With regard to the power capacity cost, PHS and Li-ion batteries with $500-3600 € / \mathrm{kW}$ and $700-3000 € / \mathrm{kW}$ respectively are currently the most expensive technologies. However in hydrogen storage, apart from the value indicated on Table 2, there is also another value stated in the literature that is associated with fuel cells. So according to [51] the cost of fuel cells is in the range of $500-8,000 € / \mathrm{kW}$, a value that could render hydrogen storage the most expensive option. Such high cost though is expected to reduce as the technology develops. $\mathrm{NaNiCl}$ batteries which cost about $100-200 € / \mathrm{kW}$ is the most economical option, while flywheels with $100-300 € / \mathrm{kW}$ and SMES and EDLCs with 100-400€/kW are also considered low-priced options. As far as energy capacity cost is concerned, SMES, flywheels and EDLCs have the highest investment cost of some thousands $€ / \mathrm{kWh}$, while hydrogen is the lowest-priced storage option with only $1-15 € / \mathrm{kWh}$. CAES systems also have a quite low cost of under $50 € / \mathrm{kWh}$.

Apart from the capital costs, the operation and maintenance (O\&M) costs are an important economic factor to consider for EES deployment. Table 3 shows the annual O\&M costs of EES technologies. O\&M costs are expressed in $(\$ / k W-y)$ and a distinction has been made as regards O\&M costs for bulk energy storage, distributed generation and power quality applications. For hydrogen energy storage, separate O\&M values are provided for systems using a fuel cell and systems using a gas turbine. O\&M costs associated with the electrolyzer are not available for this technology. 
Table 3: Operation and maintenance costs of EES technologies [38]

\begin{tabular}{|c|c|c|c|c|}
\hline & \multicolumn{3}{|c|}{ O\&M costs (\$/kW-y) } \\
\hline & & $\begin{array}{l}\text { Bulk energy } \\
\text { storage }\end{array}$ & $\begin{array}{l}\text { Distributed } \\
\text { generation }\end{array}$ & $\begin{array}{l}\text { Power } \\
\text { quality }\end{array}$ \\
\hline \multicolumn{2}{|r|}{ PHS } & 2.5 & N/A & $\mathrm{N} / \mathrm{A}$ \\
\hline \multicolumn{2}{|r|}{ CAES } & 2.5 & 10 & N/A \\
\hline \multicolumn{2}{|r|}{ Hydrogen } & N/A & $\begin{array}{c}3.8 \text { (fuel cell) } \\
2.5 \text { (gas turbine) } \\
\text { N/A (electrolyzer) }\end{array}$ & N/A \\
\hline \multicolumn{2}{|r|}{ Flywheel } & $\mathrm{N} / \mathrm{A}$ & $\$ 1000 /$ year $^{a}$ & $5^{b}$ \\
\hline \multicolumn{2}{|r|}{ SMES } & N/A & N/A & 10 \\
\hline \multicolumn{2}{|r|}{ EDLC } & N/A & N/A & 5 \\
\hline \multirow{3}{*}{ 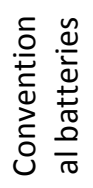 } & $\mathrm{Pb}$-acid & 5 & 15 & 10 \\
\hline & $\mathrm{NiCd}$ & 5 & 25 & \\
\hline & NiMH & N/A & N/A & N/A \\
\hline \multirow{3}{*}{ 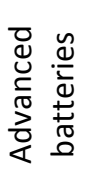 } & Li-ion & $\mathrm{N} / \mathrm{A}$ & 25 & 10 \\
\hline & NaS & 20 & N/A & N/A \\
\hline & $\mathrm{NaNiCl}$ & N/A & $\mathrm{N} / \mathrm{A}$ & $\mathrm{N} / \mathrm{A}$ \\
\hline \multirow{3}{*}{ 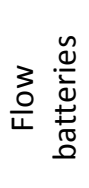 } & V-Redox & $\mathrm{N} / \mathrm{A}$ & 20 & N/A \\
\hline & $\mathrm{ZnBr}$ & N/A & 20 & N/A \\
\hline & Zn-air & N/A & N/A & $\mathrm{N} / \mathrm{A}$ \\
\hline
\end{tabular}

${ }^{a}$ The costs are specific to a $18 \mathrm{~kW} / 37 \mathrm{kWh}$ flywheel system and are not generic

${ }^{b}$ The costs refer to either high or low speed flywheel system

Based on the available literature, it seems that for bulk energy storage applications, high temperature $\mathrm{NaS}$ batteries have the highest O\&M costs and $\mathrm{Pb}$-acid batteries come second. With regard to small scale distributed systems, flywheels of the assumed power and energy ratings are significantly expensive to run, while NiCd and $\mathrm{Li}$-ion batteries are considered to score high in terms of O\&M costs. NaS, V-Redox and $\mathrm{ZnBr}$ systems could also present relatively high values for their O\&M when used in decentralised generation. For power quality applications, $\mathrm{Pb}$-acid, Li-ion and SMES technologies are the costliest of all in terms of O\&M.

As regards the spatial requirements for each technology, it seems that rechargeable Zn-Air systems have the highest potential for space saving in the future, exhibiting a remarkably high energy density value. Hydrogen storage has the highest energy density among the currently commercial storage technologies and also a very small footprint of 0.005 to $0.06 \mathrm{~m}^{2} / \mathrm{kWh}$. Zn-Air batteries are expected to be introduced to 
the market in 2013/14. Figure 4 below presents a volume comparison considering the power density (Watts/litre of storage facility) and energy density (Watt-hours/litre of storage facility) of each EES technology. The higher the power and energy density, the lower the required volume for the storage system. In other words, the more Watts or Watt-hours per litre of storage system a storage technology provides, the less volume it will require. Highly compact EES technologies suitable for mobile applications can be found at the top right. Large area and volume-consuming storage systems are located at the bottom left. PHS, CAES and flow batteries have a low energy density and are large-area and volume consuming storage systems. On the contrary, Li-ion batteries have both a high energy density and high power density, which is why Li-ion is currently used in a broad range of applications.

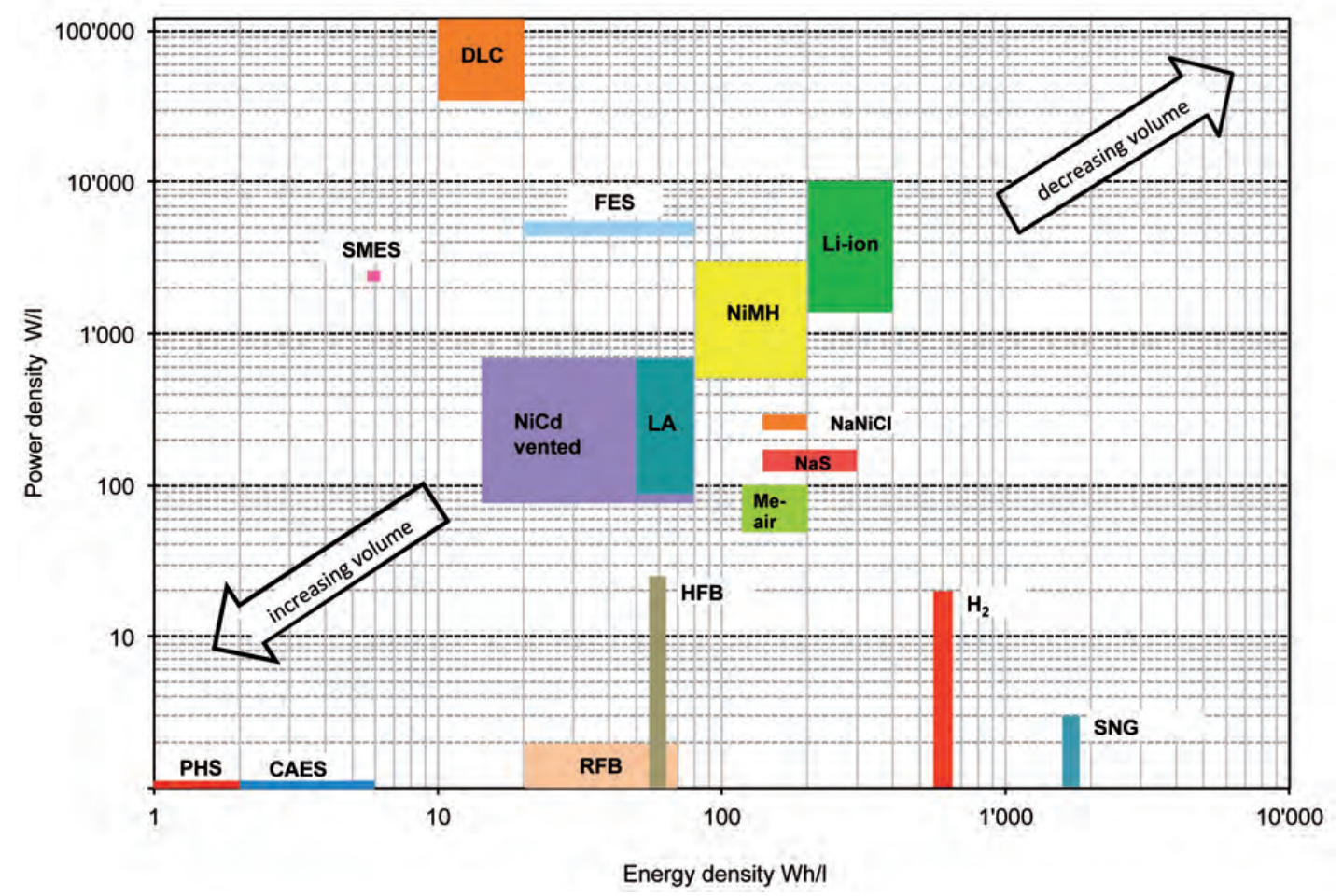

Figure 4: Comparison of power density (Watts/litre of storage facility) and energy density (Watt-hours/litre of storage facility) of EES technologies

$[26,52]$ (after Schwunk 2011)

EES technologies have varying environmental impacts and most of them score high. PHS and CAES have the highest environmental impact, as both and require a largescale infrastructure and are dependent on specific geographic and geological structures [42]. Considering the potential hazards due to the toxicity of the materials contained in some technologies, lead, cadmium and bromine found in lead-acid, NiCd and $\mathrm{ZnBr}$ batteries respectively are considered to be related with such issues. Flywheels are considered to have the smallest environmental impact during normal operation, as they have no significant emissions and no noise disturbance is generally 
caused $[42,51,53]$.

There is a wide recharge time range for the EES technologies. It seems that the conventional and the advanced batteries need the most time to be fully charged once they are fully discharged, as nearly all need some hours to be recharged. Among the battery technologies, Li-ion batteries can have the lowest recharge time, which ranges from minutes to hours [32]. Lead-acid and NaS batteries have the longest recharge times, which cannot be less than 8 hours $[42,54]$. PHS and CAES systems, flywheels, EDLCs and V-redox batteries may require a period of some minutes to be recharged, while hydrogen storage systems using the fuel cell technology can operate continuously, so long as they are supplied with fuel $\left(\mathrm{H}_{2}\right)[51]$.

Another characteristic that is included in Table 2 is the memory effect associated mainly with battery storage. This is explained as "a reduced discharge capacity when the battery is incompletely discharged and recharged" [32]. In other words, the batteries will only take full charge after a series of full discharges [4]. Memory effect is a disadvantage of $\mathrm{NiCd}$ and $\mathrm{NaNiCl}$ batteries and is associated with the nickel metal that these technologies contain. According to [4] proper battery management procedures can help to mitigate this effect.

A parameter that is also associated with batteries is the critical voltage. Critical voltage or cutoff voltage is the lowest voltage value at which battery discharge is considered complete and it is usually prescribed so as to allow maximum realization of the useful capacity of the battery $[55,56]$. If the battery voltage falls below this value, an amount of the battery capacity can be lost or even the battery can be seriously damaged $[56,57]$. It is of great importance, therefore, to end the discharge of the battery when its voltage reaches the lowest acceptable value, so as to protect it from over-discharging. This will subsequently have a positive impact on the service life of the battery [58]. Li-ion batteries have the highest critical cell voltage of 3.0V, while a $\mathrm{ZnBr}$ cell's critical voltage is found to be as low as 0.17-0.3V [56-60].

Depending on the nominal voltage of the battery cell, the cell should not go below a certain percentage of no load, full-charge voltage. For example, Li-ion cells' nominal voltage is $4.2 \mathrm{~V}$, which means that Li-ion batteries' voltage is not supposed to go below $71 \%$ of no load, full-charge voltage. In the same way, $\mathrm{ZnBr}$ batteries' voltage levels should remain over $10-17 \%$ of their no load, full-charge voltage ( $\mathrm{ZnBr}$ nominal cell voltage at $1.8 \mathrm{~V}$ ). V-Redox and $\mathrm{Zn}$-air technologies also have relatively low cutoff voltage values per cell [61-64].

Li-ion and $\mathrm{NaNiCl}$ batteries are maintenance-free technologies as [42] observe. Supercapacitors also have very low to no maintenance requirements according to $[10,42]$ and [26] respectively. There are quite a few technologies that require high maintenance and these are hydrogen, $\mathrm{NiCd}, \mathrm{NiMH}$ and $\mathrm{ZnBr}$ batteries $[38,42,65]$. 
The rest of the technologies have relatively low maintenance requirements.

Most technologies are found to be recyclable; some of them in a bigger extent, while others in a smaller one. Lead-acid batteries have a great recyclability, as more than $97 \%$ of all battery lead can be recycled [66]. $\mathrm{NaS}, \mathrm{NaNiCl}, \mathrm{V}$-redox and $\mathrm{ZnBr}$ batteries also have very high recyclability. The other technologies are considered to have a medium recyclability, while hydrogen storage is assumed to have the lowest recyclability rating.

The technical maturity achieved for each technology is shown quantitatively and the EES technologies can be classified into three categories: mature technologies, technologies of medium maturity and technologies in an early development stage. Only PHS and lead-acid batteries, which have been used for over 100 years, are currently mature and well-researched technologies and available for high and medium power ranges and energy capacities respectively. CAES, flywheels, SMES, EDLCs, NiCd, Li-ion, $\mathrm{NaS}, \mathrm{NaNiCl}$ and flow batteries are technologies of medium technical maturity regarding large-scale applications, while $\mathrm{NiCd}, \mathrm{NiMH}$, Li-ion and $\mathrm{NaNiCl}$ batteries exhibit considerable maturity in portable or mobile applications. Regarding large-scale deployment, these technologies are technically developed and commercially available, but their competitiveness and reliability still need to be proven, as there are very few actual examples of their deployment [4]. Hydrogen, SMES and Zn-Air batteries are still under development, while their technical suitability for various applications has already been tested. It was not until very recently that hydrogen and SMES storage technologies were commercialised. Zn-Air batteries are expected to be commercialised in 2013/2014. Moreover, according to [3], technical maturity is found to be inversely proportional to the cost and this is possibly due to mass production and the learning effect. There is currently a great deal of research and development around for all EES technologies aiming at increasing their technical maturity levels and at commercialising advanced modules. Consequently the competition among the top manufacturing companies in the electricity storage market, who can be found in $[42,67]$ is tight and can potentially lead to rapid developments in this field.

Regarding the flexibility of the discussed technologies, not all storage systems are transportable, meaning that some have to be constructed on site, while others can be pre-constructed and then transferred to the desired area. The technologies that have the limitation of non-transportability are PHS, CAES and V-redox batteries. All other technologies can be transported to the desired site under specific safety conditions.

Comparing the cumulative energy demand of the technologies for which there were sufficient data in the literature, lead-acid batteries have the lowest value of 652 $\mathrm{MJ} / \mathrm{kWh}$. Zn-air batteries are the second most sustainable option with a value of 710 
$\mathrm{MJ} / \mathrm{kWh}$, while flywheels are found to have the highest energy demand for their material supply with an exceptionally high value of $30,449 \mathrm{MJ} / \mathrm{kWh}$.

The comparison among the storage technologies above makes clear that no single EES technology scores high in all the parameters discussed. For example, batteries of one type or the other can address all application areas, although they are not always the least expensive option [38]. Li-ion batteries offer good power capability, high energy density, high efficiencies, light weight and small footprint, but they are still expensive and also further R\&D is required to prove their suitability for large-scale applications including solar and wind plants. There are also safety issues associated with their operation, as is the case for $\mathrm{NiCd}$ and $\mathrm{NaS}$ batteries. High temperature $\mathrm{NiCd}$ and $\mathrm{NaNiCl}$ batteries also suffer from memory effect. In addition, lead-acid batteries are a state-of-the-art technology for PV energy storage and UPS systems and currently have the lowest invest per kWh. However, they have a relatively limited lifetime and the image of "old" technology [7]. Zn-air batteries potentially offer high gravimetric and volumetric energy density and low materials cost, but they suffer from low round-trip efficiencies compared to other battery systems and there is no such system available in the market yet. Redox-flow batteries are versatile systems and an interesting option for bulk energy storage, but further development is required so that their suitability for such applications is demonstrated. They also have a very low power density.

PHS and CAES systems have long lifetimes and practically unlimited cycle stability, but they are dependent on suitable topographical conditions. Therefore they have a high environmental impact, as they require large areas of land, possibly substituting the existing land use. Moreover, hydrogen storage is considered to be a promising technology regarding storage of large amounts of energy up to the TWh range and for very long periods of time, but the its overall efficiency is still low.

Flywheels have excellent cycle stability and long lifetime, high power density, high efficiency and low maintenance requirements, yet they can lose all their stored energy within one day if they are in standby mode. SMES devices have a very fast response time, rapid discharge rates and the highest power density among highpower EES technologies, but they are very sensitive to temperature. EDLCs are capable of operating over a broad temperature range, have long lifetime, little maintenance, very fast charging and discharging times, but also very low specific energy values.

Therefore, several factors should be taken into consideration when planning the integration of a storage system in the built environment. As [32] observe, the selection of the most preferable technology for a specific application depends on the size of the system, the specific service, the electricity sources and the marginal cost of peak electricity. Moreover, according to [68], the socio-economic acceptability of 
the storage system could constitute a challenge in the case of EES at community level.

\subsection{Metal resource availability}

The limited quantity of minerals and resources on Earth along with the world metal resource consumption rate has a direct impact on the availability regarding the metals used in EES technologies. This is quite likely to affect the deployment of certain EES technologies in the long term.

Table 4 shows the available time frame of metals associated with EES technologies in the future according to their current consumption rates. Most metal reserves and especially those with high substitutability are unlikely to run out over the coming decades. In other words, EES technologies such as PHS, CAES, flywheels, EDLCs and SMES have a flexibility regarding the suitable metals for their construction and thus a considerably lower risk in terms of material supply shortage.

On the other hand, $\mathrm{Mg} / \mathrm{Sb}$, lead-acid, $\mathrm{ZnBr}$ and $\mathrm{Zn}$-Air batteries may be the first to face supply shortage as they contain irreplaceable metals. According to [65], there would only be approximately 10 years of available supply reserves for Antimony and around 20 years of reserves for Lead and Zinc.

Table 4: World's metal reserves for EES [69]

\begin{tabular}{|l|l|l|l|l|}
\hline Metal & EES usage & $\begin{array}{l}\text { Reserves } \\
\text { (ktons) }\end{array}$ & $\begin{array}{l}\text { Yearly use } \\
\text { (ktons) }\end{array}$ & $\begin{array}{l}\text { Years left } \\
\text { (current cons. rate) }\end{array}$ \\
\hline Antimony & $\mathbf{M g} /$ Sb & $\mathbf{1 , 8 0 0}$ & $\mathbf{1 6 9}$ & $\mathbf{1 0 . 7}$ \\
\hline Bismuth & SMES & 320 & 8.5 & 37.7 \\
\hline Barium & SMES & 240,000 & 7,800 & 30.8 \\
\hline Copper & SMES & 690,000 & 16,100 & 42.9 \\
\hline Helium & SMES & $31,300 *$ & $180 *$ & 173.9 \\
\hline Lead & Lead-acid, SMES & $\mathbf{8 5 , 0 0 0}$ & $\mathbf{4 , 5 0 0}$ & $\mathbf{1 8 . 9}$ \\
\hline Lithium & Li-ion & 13,000 & 34 & 382.4 \\
\hline Magnesium & SMES, fuel cell, Mg/Sb & $\mathrm{N} / \mathrm{A}$ & 0.78 & $>1000$ \\
\hline Nickel & NiCd, NaNiCl, fuel cell & 80,000 & 1,800 & 44.5 \\
\hline $\begin{array}{l}\text { Palladium/ } \\
\text { Platinum }\end{array}$ & Fuel cell & 66 & 0.40 & 165 \\
\hline Sodium & NaS & & & \\
\hline Strontium & SMES & $3,300,000$ & 6,000 & 550 \\
\hline Titanium & Flywheel, fuel cell & 6,800 & 380 & 17.9 \\
\hline Vanadium & V-redox & 14,000 & 60 & 23.1 \\
\hline Yttrium & SMES & 540 & 8.9 & 60.7 \\
\hline Zinc & ZnBr, Zn-Air & $\mathbf{2 5 0 , 0 0 0}$ & $\mathbf{1 2 , 4 0 0}$ & $\mathbf{2 0 . 2}$ \\
\hline Zirconium & Fuel cell & 52,000 & 1,410 & 36.9 \\
\hline
\end{tabular}

$*$ in million $\mathrm{m}^{3}$ 
However, several factors such as technology improvements, the use of alternative materials and the discovery of new reserves can affect minerals' consumption rates in the future. Hence, their date of depletion is a moving target and an EES technology should not be discounted as an option solely because of lack of alternatives [3]. In addition, the recycling of the metals is expected to play an important role in extending their time frame and in mitigating potential environmental impacts.

\subsection{Worldwide scale of EES installations}

There are a number of electricity storage installations worldwide, addressing a wide range of applications. Figure 5 shows the worldwide installed storage capacity of systems used in electricity grids.

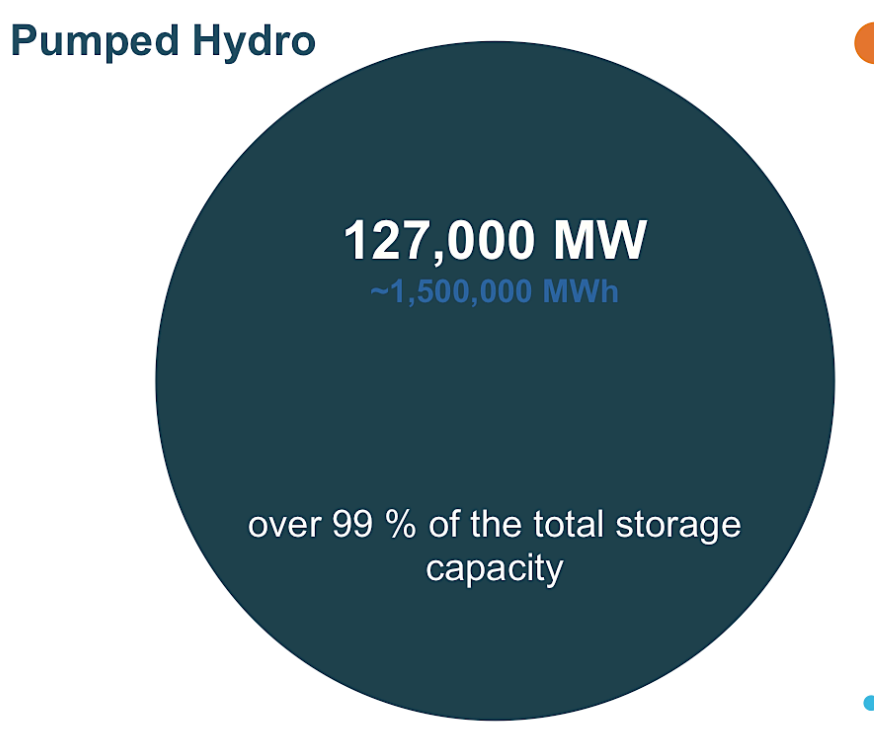

Compressed Air Energy Storage 440 MW 3,730 MWh

Sodium Sulphur Battery 316 MW 1,900 MWh

- Lithium Ion Battery $\sim 70 \mathrm{MW} \sim 17 \mathrm{MWh}$

- Lead Acid Battery 〜35 MW 70 MWh

- Nickel Cadmium Battery 27 MW 6,75 MWh

- Flywheels $<25 \mathrm{MW}<0,4 \mathrm{MWh}$

- Redox Flow Battery $<3 \mathrm{MW}<12 \mathrm{MWh}$

Figure 5: Worldwide installed storage capacity for electrical energy [12]

According to figure 5, PHS systems currently hold by far the biggest share, with a worldwide installed capacity of $127,000 \mathrm{MW}$. PHS plants represent about $3 \%$ of the global generation capacity and account for over $99 \%$ of the total installed storage capacity. The remaining storage capacity of less than $1 \%$ belongs to CAES systems with $440 \mathrm{MW}$ installed, NaS batteries with $316 \mathrm{MW}$ installed and other technologies totalling less that $85 \mathrm{MW}$ [12]. As regards the three most widely used EES systems, approximately 270 PHS plants are currently in operation or under construction [70], only 2 CAES systems have been installed [11, 12, 25, 26, 30, 37] and about $223 \mathrm{NaS}$ systems are operational [26]. Moreover, PHS systems have been installed in several locations, such as in Europe, USA, China, India and Japan. The two CAES units are located in USA and Germany, while NaS installations can be found in Japan, Germany, France, USA and UAE $[26,70]$. As it is anticipated though, a larger need for EES will 
emerge in the future, and as a consequence a larger quantity of EES systems will be installed around the globe.

Given the large introduction of renewable energy technologies, the International Energy Association (IEA) projects that an installed EES capacity of $189 \mathrm{GW}$ or $305 \mathrm{GW}$ will be needed by 2050 [71]. The different capacity numbers depend on the variation of output from renewable resources, which in the two cases was assumed to be $15 \%$ and $30 \%$ respectively. Bearing in mind that the total EES capacity today is $127 \mathrm{GW}$, IEA's estimation for the two scenarios translates to 1.5 or over two times as much of today's EES. A high number of EES systems are likely to be installed in Western Europe and China, as in these areas a rapid deployment of renewable energy technologies is expected to emerge [71]. Furthermore, if the batteries of electric cars are used to inject and absorb electrical energy to and from the grid as needed, the projected worldwide EES capacity by 2050 can be lower. In case this concept is adopted, the EES capacity can be decreased from $189 \mathrm{GW}$ to $122 \mathrm{GW}$ or from 305 GW to $280 \mathrm{GW}$.

\subsection{EES current market status and future trends}

\subsubsection{Emerging EES applications}

Commercial deployment has been achieved so far for some EES applications concerning utility use and consumer use. For instance, as regards utility use, PHS and CAES are currently being used for time shifting purposes and power quality. In addition, $\mathrm{Li}$-ion and $\mathrm{Pb}$-acid batteries are used today to provide more efficient use of the power network, to provide utilities with emergency power supply or to meet the varying demand in isolated grids. As for consumer use, NaS batteries are currently used in large factories, commercial buildings and schools providing load leveling as well as improved reliability and quality of power supply [26].

Electricity storage will continue to be used for these applications in the future and it will serve some new applications too. The new applications include the expansion of renewable energy generation, the smart grid and the electrification of the transport sector, which all will be of great importance to the built environment of the future. In fact, storage applications will be primarily used in combination with renewable energy generation and the energy storage market is expected to increase 20 -fold between 2010 and 2020 [32]. Renewable energy will be able to be stored in the kW, MW and GW scales through centralised or decentralised systems and as [26] observes, there will be an increase in distributed generation, where consumption and generation are typically close together.

With the development of smart grids, the electricity network will change from passive to active including consumer participation [7, 26]. In other words, instead of power flows in one direction only -from centralised plants to consumers- there will 
be bi-directional power flows contributing to the efficient and rational management of the overall power system [2]. Electricity storage on this occasion will help enhance frequency control capability and can also be used for demand-side management purposes. For smart grid applications, $\mathrm{Pb}$-acid, $\mathrm{NaS}$, Li-ion and $\mathrm{V}$-Redox batteries are considered to have high potential. Smart buildings that will form part of smart grids are expected to play a key role in the future intelligent power networks. Hence, the concept of the Smart House, which is designed to use energy more efficiently, economically and reliably, is also expected to integrate EES technologies [72]. Figure 6 schematically represents the concept of the Smart House. Currently lead-acid batteries are mainly used in smart houses, but in the future Li-ion or $\mathrm{NaNiCl}$ batteries in particular are expected to play an important role because of their high cycle lifetime and their high peak power capability [5].

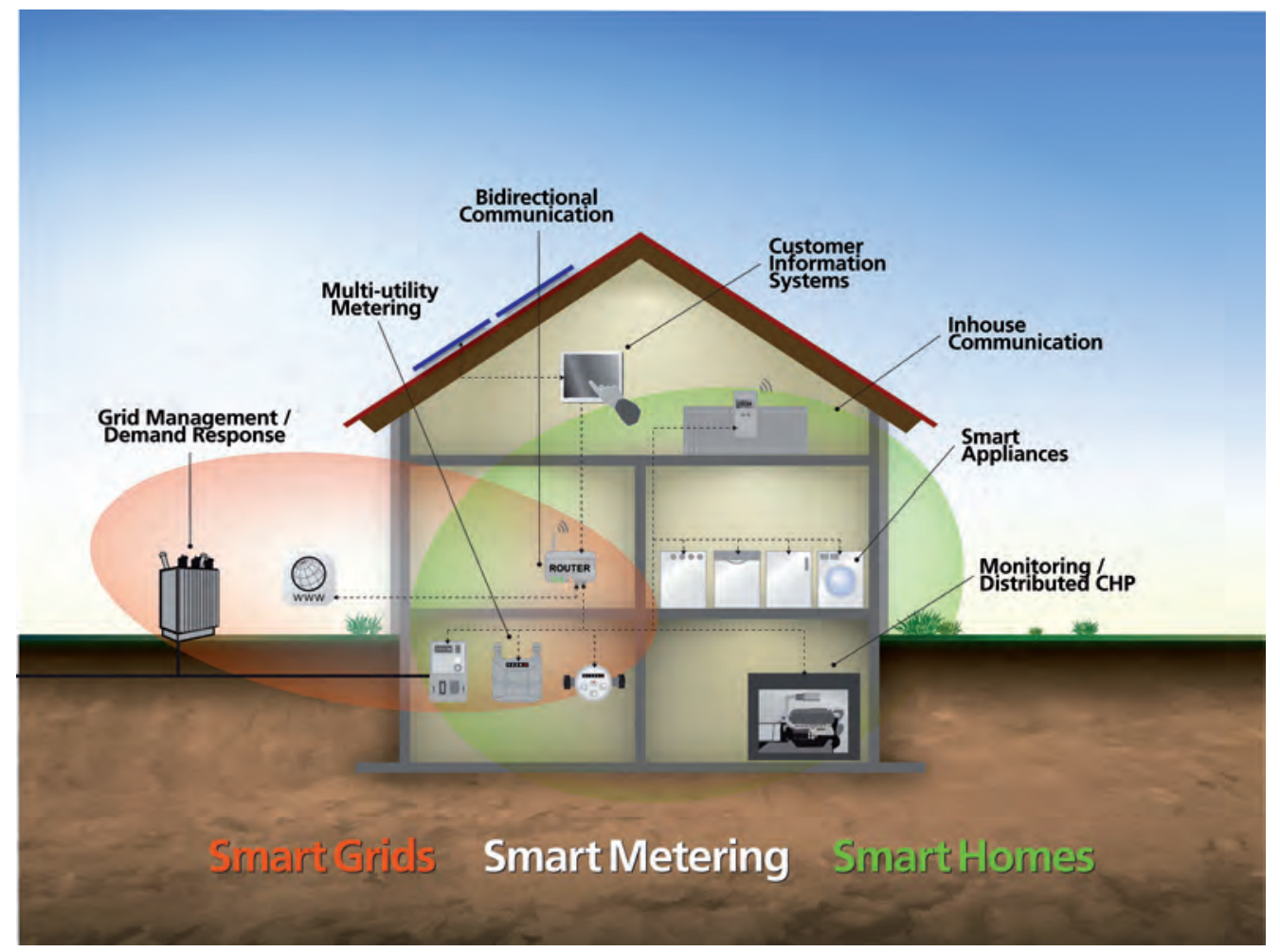

Figure 6: The Smart House [26, 52] (after Schwunk 2011)

In addition, according to [11] and [26], the emerging interaction of the electricity supply system and the transport sector is an important point to address for a sustainable future. Therefore, large-scale decentralised energy storage could be achieved through the use of the battery bank in plug-in hybrid and full electric vehicles; and this is a means for using existing storage systems to supply the electric grid. The vehicles could assist when the peak load in the grids occurs, through their charge and discharge power capability, so any diurnal fluctuations could be easily resolved $[11,37,73]$. Today $\mathrm{Pb}$-acid and $\mathrm{NIMH}$ batteries are mainly used in hybrid 
vehicles. However, as Li-ion batteries are becoming technically more attractive and are ideally suited for both hybrid and electric vehicle applications, it is anticipated that they will play a central role in the electrification of transport. $\mathrm{NaNiCl}$ batteries could also be used in pure electric vehicles and preferably in fleet vehicles $[11,30]$.

\subsubsection{Hybrid EES systems}

As each storage technology has its own strengths and weaknesses, complementary EES technologies can be coupled to form hybrid systems, so as to increase the range of services that a singe storage system can provide. For example, batteries could be used in conjunction with other electricity storage technologies, such as EDLCs [10, 13, $26,32,42$ ]; flywheels could be possibly used in combination with technologies that deliver higher energy, such as pumped hydro systems or batteries [39]; SMES could be coupled with hydrogen storage $[39,74]$; or CAES could synergise with flywheels to increase their response time and deliver power in milliseconds $[42,75]$. By combining different technologies on the same storage site, benefits can be maximised and costs can be reduced. Usually a high power EES technology is coupled with a high energy one, so as to benefit from the complementarity of the characteristics that each one has.

A potential future applicable storage solution that has been proposed and investigated by two German Institutes is a hybrid system combining SMES and liquefied hydrogen storage, called LIQHYSMES [74]. Hydrogen with its high energy density is a good candidate for bulk energy long-term energy storage. Though it has limited capability of handling short-term fluctuations for periods of seconds and also has relatively slow discharge and low cycle efficiency. In order for this requirement to be addressed, SMES with fast charge and discharge at higher efficiencies could be an additional storage option to hydrogen. Therefore, SMES, as high power EES option, can fill this gap, covering the short-term fluctuations and addressing the power quality aspect.

Simulations indicated that the LIQHYSMES system is capable of dealing with strong fluctuating imbalances between supply and demand for a variety of time scales from hours to seconds [74]. Consequently, it could be used for the large-scale grid integration of intermittent renewable energy sources providing both long-term energy balancing and short-term power quality and frequency regulation.

Hybrid storage systems, such as the one described above are expected to provide increased operational safety, greater efficiencies, improved lifetime and reduced costs $[39,74]$, so the use of multifunctional hybrid EES systems is considered to be a favourable option in the future. However, further research and development need to be undertaken so that their feasibility is demonstrated in multiple applications. Moreover, the establishment of a joint platform involving different actors of the 
storage arena, such as research institutes, manufacturers and utilities, could provide the interdisciplinary collaboration which is needed to make further progress in this field [39].

\subsubsection{EES deployment potential}

As regards the deployment potential of electricity storage in the future, the market volume is dependent on how the renewable energy ratio will develop and also varies regionally. In addition, technological advances and cost reductions will enable the rapid growth of the EES market [26]. Conventional bulk-energy storage technologies, such as PHS and CAES seem to be favourable as they can be coupled with large wind farms or large solar photovoltaic power plants and provide electrical energy for periods from a couple of hours to one day. Yet some countries, such as Germany and Japan [26], may be faced with lack of appropriate geographical formations for the application of such large systems, so this again highlights that the EES deployment potential is area dependent. Moreover, due to the high number of pumped hydro plants already deployed, it is estimated that there is only about $25 \%$ of the total potential for hydropower in Europe left today [42]. According to [76], experts estimate that the market line for advanced PHS systems capable of being integrated holistically into the future smart grid ranges from 3 to 10 years. As for compressed air storage, adiabatic CAES, whose reliability and viability will be demonstrated in the following years, might be able to be commercialised in 2020. In line with compressed air storage, the commercialisation of liquid air storage, whose concept has been proven on industrial scale, is likely to emerge in 2020's [26].

For the MW/MWh scale, rechargeable batteries such as Li-ion, NaS and V-redox technologies are expected to be widely used, providing electricity for some hours or days. Especially for Li-ion systems, due to their future potential expansion of uses, such as in portable electronics, in electric mobility or in distributed and stationary storage, one would think that careful consideration should be given with respect to the lithium resource availability $[26,69,76]$. Interestingly, however, studies show that even by employing the highest demand scenario for lithium technology, by 2100 , only half of the currently available lithium resources will be needed [42]. Generally for battery technologies, according to [76], it is anticipated that a period of 5 to 15 years will be needed for their wide deployment in decentralized and centralized systems.

For longer periods of days to months, hydrogen is considered to be appropriate, but further development needs to take place. Therefore, hydrogen is unlikely to be among the key technologies in electrical energy storage in the near future, as it does not have high storage efficiencies. High efficiencies, however, are considered to be a prerequisite for efficient electricity storage $[11,37]$. Under these circumstances, 
experts' estimates as to how long it will take for hydrogen storage to be commercially available in large volumes vary from 10 to 40 years.

Distributed storage through batteries in electric vehicles is anticipated to attract interest in the future EES market, but these alone will not be able to cover $100 \%$ of the future storage demand [26]. The emergence of this sector is expected to give a considerable boost to the further development of battery technologies [76], creating various opportunities for collaboration among existing and new actors in the field. Hence, there is a high market potential for such technologies in the future and perhaps the extensive research and development leads to the emergence of new and more advanced battery systems.

Figure 7 shows EES technologies' present and future feasibility for specific applications indicating which ones need further research and development.

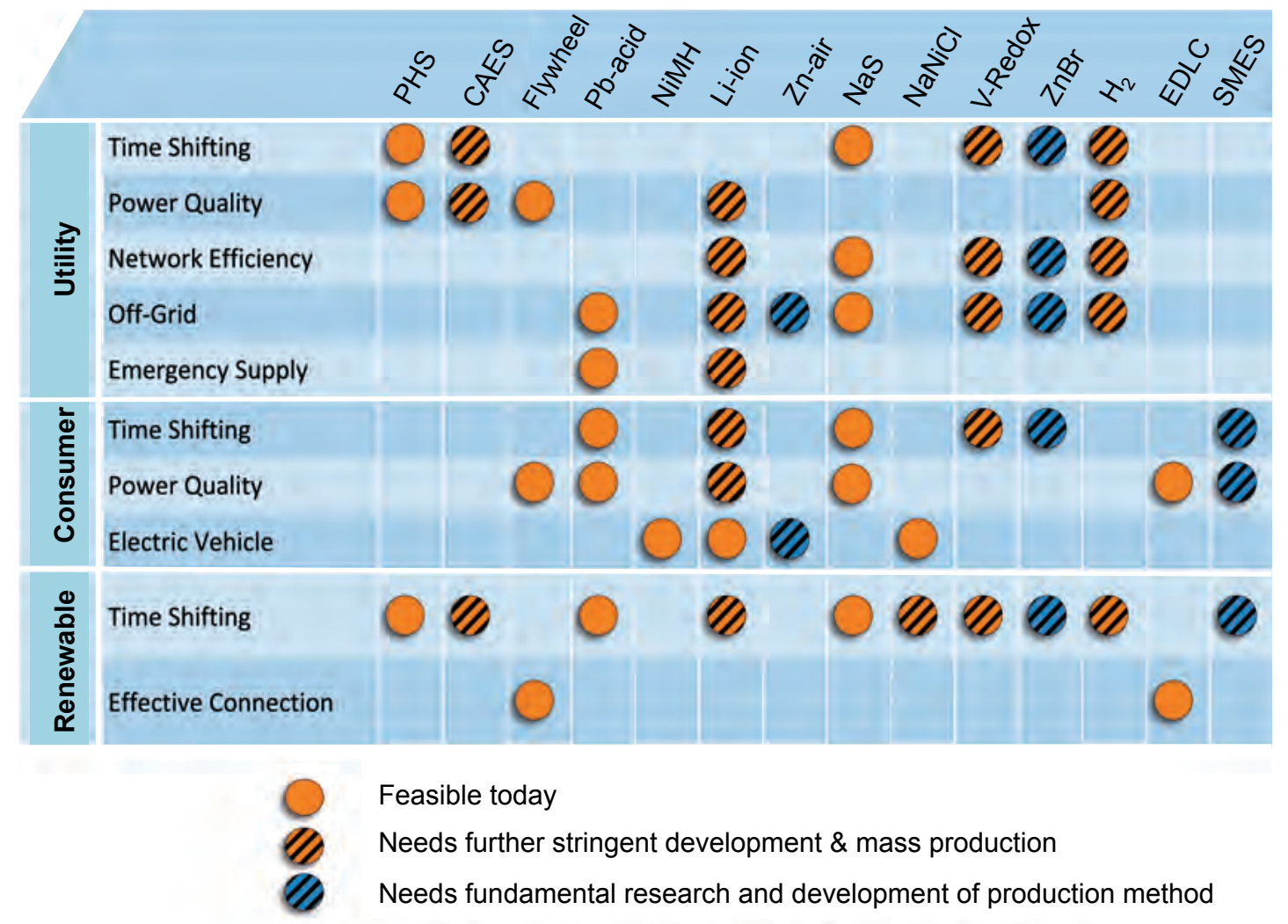

Figure 7: EES present feasibility, future potential, need for further research and development [26, 52] (after Schwunk 2011)

In addition to what has been discussed above, and according to Figure 7, Li-ion technology will be ideal for a range of applications being the most versatile of all. As the Panasonic Group observe [5], Li-ion battery market is expected to have a steady increase in the future including both small- and large-scale applications. Further research and development is needed though, so as to reduce costs and achieve mass production. Along with Li-ion, CAES, V-Redox and hydrogen systems all used for time 
shifting and especially in utility applications are also in need of further stringent development and mass production. Finally, fundamental research and development is necessary for $\mathrm{Zn}$-Air, $\mathrm{ZnBr}$ and SMES systems, so that efficient and reliable production methods are achieved.

Flywheels and EDLCs are feasible today and are expected to be involved in the market of distributed generation particularly providing voltage and frequency stabilisation to the grid in about 10 years [76]. Yet, these systems are and will be challenged by the rapid development of technically better solutions, like Li-ion, which are economically feasible and can provide a range of services apart from pure power services $[26,76]$. In addition, flywheels are not likely to be used in residential applications in the near future, as they are relatively expensive and there are still safety issues associated with their operation [42]. EDLCs could be a suitable technology for the future smart grid, as when coupled with batteries, they can complement the long-term battery storage by smoothing out short interruptions [42]. The broader range of applications that EES technologies will be likely to address in the future is a favourable factor for their greater deployment. As EPRI remarks [10], EES options will be more attractive to power producers and retailers if a single storage technology can be used for multiple applications simultaneously, maximising the benefits and the revenues.

The anticipated use of more renewable energy, the aim towards further reduction of carbon emissions and the emergence of smart grids are expected to develop electricity storage into a central element of the future power systems [26]. As [11] claims, today it is still difficult to give an estimation of how much storage capacity would be needed in the built environment if electricity were to be generated mainly from renewable energy sources. This question could only be addressed through a comprehensive study that would picture the optimal mix of technologies. Moreover, according to the European Commission, the main challenge for a speedy deployment of EES is economic and the adoption of new, European rules could accelerate the development of EES systems through a pan-European collaboration [76]. Another important issue is the future development of transmission grid structures, as the requirement for long-term storage installations will be smaller if the electrical energy transport capacities become larger [73]. In any case, given the benefits electricity storage can provide in an expanding system services market, it is expected to be a competitive solution in the RES-dominated future built environment [2].

\section{Conclusions}

A comprehensive review regarding the main characteristics of the electricity storage technologies and their significance within different applications in the built environment have been presented in this paper. The building sector could provide 
opportunities in the electric grid and its interaction with the supply system is very likely to emerge. There is a great potential to reduce the carbon footprint of the built environment by managing electricity through storage. As some types of storage technologies are already in use and others are still in the development phase, recent advances on the improvement of several performance parameters have been included in this review. It is concluded that there is at least one solution currently available for each type of application, yet more and more application possibilities will emerge due to the continuous research and development in the field. However, the development will take new dimensions if the research is focused on interinstitutional and inter-continental collaboration and is not undertaken by independent stakeholders.

Li-ion batteries and metal-air (Zn-Air) batteries with energy densities of $620 \mathrm{kWh} / \mathrm{m}^{3}$ and $800 \mathrm{kWh} / \mathrm{m}^{3}$ correspondingly seem to be very promising technologies for advanced EES integration in the built environment. Along with these technologies, $\mathrm{NaNiCl}$ batteries are also expected to play an important role in buildings because of their high cycle lifetime and high peak power capability. However, there is still room for improvement of the technologies' properties, so as to increase the systems' efficiencies, lower the costs and extend the lifetimes. The use of hybrid systems that benefit from the complementary properties of storage technologies could be a possible option to achieve improved performance of EES systems. A shift from the currently passive network to an active network is also of great importance in line with the emergence of smart grids. Smart buildings of all sorts of uses and storage systems at a variety of scales, which could link in the electric vehicle fleet, are expected to synergize in the modern built environment of the future.

\section{References}

[1] European Commission. Energy infrastructure priorities for 2020 and beyond: A Blueprint for an integrated European energy network. Communication from the commission to the European parliament, the council, the European economic and social committee and the committee of the regions. 2010.

[2] Alba Rios JJ, Birkner P, Hakan F, Kroll A, Lawson P, Lebreton P, et al. Decentralised storage: impact on future distribution grids. Brussels, Belgium: Union of the Electricity Industry, 2012.

[3] Beaudin M, Zareipour H, Schellenberglabe A, Rosehart W. Energy storage for mitigating the variability of renewable electricity sources: An updated review. Energy for Sustainable Development. 2010;14(4):302-14.

[4] Chen H, Cong TN, Yang W, Tan C, Li Y, Ding Y. Progress in electrical energy storage system: A critical review. Progress in Natural Science. 2009 Mar 10;19(3):291-312. PubMed PMID: WOS:000263557200003. 
[5] Inage S. Prospective on the Decarbonised Power Grid. IEC/MSB/EES Workshop; 201131 May-1 June 2011; Germany.

[6] Ibrahim H, Ilinca A, Perron J. Energy storage systems - Characteristics and comparisons. Renewable \& Sustainable Energy Reviews. 2008 Jun;12(5):1221-50. PubMed PMID: WOS:000255776600002.

[7] Protogeropoulos C. Large stationary batteries for deployment in grid-connected photovoltaic and other renewable energy power plants. 2012 IFNA World CongressSolar Energy Storage; 2012 June 2012; Athens, Greece.

[8] Kintner-Meyer MC, Subbarao K, Prakash Kumar N, Bandyopadhyay G, Finley C, Koritarov VS, et al. The role of energy storage in commercial buildings: a preliminary report Richland, Washington: Pacific Northwest National Laboratory, 2010. Contract No.: PNNL-19853

[9] APS Panel on Public Affairs. Challenges of electricity storage technologies: A Report from the APS Panel on Public Affairs Committee on Energy and Environment. 2007. Available from: www.aps.org/policy/reports/popareports/upload/Energy_2007_Report_ElectricityStorageReport.pdf [10] Sandu-Loisel R, Mercier A. Technology Map of the European Strategic Energy Technolgy Plan. Luxembourg: Publications Office of the European Union, 2011. [11] Droege P. Urban energy transition: from fossil fuel to renewable power. 1 ed. Hungary: Elsevier; 2008. 664 p.

[12] Rastler D. Electric energy storage technology options: a White Paper Primer on applications, costs, and benefits. Palo Alto, California: Electric Power Research Institute (EPRI), 2010.

[13] Naish C, McCubbin I, Edberg O, Harfoot M. Outlook of energy storage technologies. European Parliament, Policy Department, Economic and Scientific Policy, 2008.

[14] German Advisory Council on Global Change. 2008 [cited 201216 April]. Available from: http://www.wbgu.de.

[15] Sandia National Laboratories. A brief history of the DOE energy storage systems research program 2012. Available from: http://www.sandia.gov/ess/overview.html. [16] Simon R. New York energy storage roadmap. Albany, New York: New York Battery and Energy Storage Technology Consortium, 2012.

[17] Rastler D. Overview of energy storage options for the electric enterprise. Palo Alto, California: Electric Power Research Institute (EPRI), 2009.

[18] National Renewable Energy Laboratory. Energy storage 2011. Available from: http://www.nrel.gov/vehiclesandfuels/energystorage/.

[19] Denholm P, Ela E, Kirby B, Milligan M. The role of energy storage with renewable electricity generation. Colorado, US: National Renewable Energy Laboratory, 2010 Contract No.: NREL/TP-6A2-47187

[20] Electricity Storage Association. About ESA 2011. Available from: http://www.electricitystorage.org/about/about_esa. 
[21] Ribeiro P, Johnson B, Crow M, Arsoy A, Liu Y. Energy storage systems for advanced power applications. Proc IEEE. 2001;89(12):4291-300.

[22] Hall P, Bain E. Energy-storage technologies and electricity generation. Energy Policy. 2008;36(12):4352-5.

[23] Hadjipaschalis I, Poullikkas A, Efthimiou V. Overview of current and future energy storage technologies for electric power applications. Renewable Sustainable Energy Reviews. 2009;13(6-7):10.

[24] Augustine C, Bain R, Chapman J, Denholm P, Drury E, Hall DG, et al. Renewable electricity future study: renewable electricity generation and storage technologies. Golden, Colorado, US: National Renewable Energy Laboratory, 2012. Contract No.: NREL/TP-6A20-52409-2

[25] Electricity Storage Association. Storage technologies 2011 [20 April 2012]. Available from:

http://www.electricitystorage.org/technology/storage_technologies/technology_co mparison.

[26] International Electrotechnical Commission. Electrical energy storage: white paper. Geneva, Switzerland: International Electrotechnical Commission, 2011.

[27] Fehrenbacher K. AES building world's largest lithium-ion battery grid projects. 2011 [cited 201315 April]. Available from: http://gigaom.com/2011/05/06/aesbuilding-worlds-largest-lithium-ion-grid-battery-projects/.

[28] Buckles W, Hassenzahl W. Superconducting magnetic energy storage. IEEE Power Eng Rev. 2000;20(5):16-20.

[29] Hassenzahl W, Hazelton D, Johnson B, Komarek P, Noe M, Reis C. Electric power applications of superconductivity. Proc IEEE. 2004:1655-74.

[30] Farret F, Simões MG. Integration of Alternative Sources of Energy. 1 ed. New Jersey: John Wiley \& Sons; 2006.

[31] Garthwaite J. How ultracapacitors work (and why they fall short). 2011 [cited 201216 April]. Available from: http://gigaom.com/cleantech/how-ultracapacitorswork-and-why-they-fall-short/.

[32] Simbolotti G, Kempener R. Electricity storage: technology brief. IEA-ETSAP and IRENA, 2012.

[33] Faulstick B. Making "renewable" viable: Drexel engineers develop new technology for grid-level electrical energy storage 2012 [cited 201211 July]. Available from: http://www.drexel.edu/now/news-

media/releases/archive/2012/July/Engineers-Develop-New-Grid-Level-EnergyStorage-Technology/.

[34] Kaufmann R. Upgrading the electric grid with flywheels and air. National Geographic. 2011.

[35] Zimmerman J, Loone C. Renewable energies in the remote areas and the top end. Electrical Engineering in the Top End 2009 - IDC Technologies; 2009 March; Darwin, Australia. 
[36] Dupont G. Smart grid applications. $1^{\text {st }}$ International ICST Conference on E-Energy; 2010 14-15 October; Athens, Greece.

[37] Roberts B. Capturing grid power. IEEE Power \& Energy. 2009.

[38] Schoenung S, Hassenzahl W. Long- vs. short-term energy storage technologies analysis: a life-cycle cost study. California, USA: Sandia National Laboratories, 2003. [39] Teller O, Nicolai JP, Lafoz M, Laing D, Tamme R, Pedersen AS, et al. Joint EASE/EERA recommendations for a European energy storage technology development roadmap towards 2030. European Association for Storage of Energy and European Energy Research Alliance. 2013.

[40] Pnu-Power. Pnu-Power 10kW compressed air battery. 2008 [cited 201324 April]. Available from: http://www.pnu-power.com/products/10kw/.

[41] Sørensen B. Renewable energy conversion, transmission and storage. 1 ed. USA: Academic Press; 2007. 344 p.

[42] Alanen R, Appetecchi G, Conte M, De Jaeger E, Graditi G, Jahren S, et al. Electrical energy storage technology review. European Energy Research Alliance, 2012.

[43] International Power. Dinorwig power station. 2012 [cited 201224 August]. Available from: http://www.fhc.co.uk/dinorwig.htm.

[44] Chinese National Committee on Large Dams. Tianhuangping Pumped Storage Power Station. 2011 [cited 201225 August].

[45] Rhodes A, Wentworth J. Electricity storage. London: Parliamentary Office of Science and Technology, 2008.

[46] Bauchmüller M. Selbstversorger Graciosa. Süddeutsche Zeitung 12 August 2012. 2012.

[47] EOS Energy Storage. Energy storage: Utility opportunity summary. 2011.

[48] EOS Energy Storage. Energy storage. 2012.

[49] Sadoway D. The missing link to renewable energy. California, USA:

http://www.ted.com; 2012.

[50] Mancey H. Rechargeable metal-air battery system. Next Generation Batteries 2012; 2012 19-20 July; Boston, USA.

[51] Connolly D. A review of energy storage technologies for the integration of fluctuating renewable energy: Limerick; 2010.

[52] Schwunk S. Battery systems for storing renewable energy. Germany: FraunhoferInstitut für Solare Energie, 2011.

[53] Schoenung S. Characteristics and technologies for long- vs. short-term energy storage: a study by the DOE Energy Storage Systems Program. California, USA: Sandia National Laboratories, 2001.

[54] Norris B, Newmiller J, Peek G. NaS battery demonstration at American Electric Power. California, USA: Sandia National Laboratories, 2007.

[55] Randolph C. Glossary of battery terms 2013 [cited 201310 April]. Available from: http://www.greenbatteries.com/batteryterms.html [56] Garche J. Encyclopedia of electrochemical power sources. The Netherlands: 
Elsevier; 2009.

[57] Large Battery. Lithium battery cutoff voltage 2011 [cited 201310 April]. Available from: http://www.large-battery.com/lithium-battery-discharge-cutoff-voltage.html [58] Buchmann I. Basics about discharging 2013 [cited 201310 April]. Available from: http://batteryuniversity.com/learn/article/discharge_methods [59] Buchmann I. Premature voltage cut-off 2013 [cited 201310 April]. Available from: http://batteryuniversity.com/learn/article/premature_voltage_cut_off/ [60] Norris BJ, Lex P, Ball GJ, Scaini V. Grid-connected solar energy storage using the zinc-bromine flow battery, 2002. Available from: www.zbbenergy.com/index.php/download_file/view/20/znbr [61] Yamamura T, Wu X, Sato I, Sakuraba H, Shirasaki K, Ohta S. Vanadium battery 2013 [cited 201310 April]. Available from: http://ip.com/patfam/en/43900326 [62] Unknown author. UNIKEN the University of New South Wales. Energy Focus, August 1995; Magazine of the NSW Department of Energy, Australia. 1995. [cited 201310 April]. Available from: http://www.oocities.org/infotaxi/VANADI4.HTM\#Swe [63] Energizer. Energizer Zinc Air prismatic handbook 2009. Version 1.2. [cited 2013 10 April]. Available from:

http://data.energizer.com/pdfs/zincairprismatichandbook.pdf

[64] Duracell. Technical bulletin 2004 [cited 201310 April]. Available from: http://www.duracell.com/media/enUS/pdf/gtcl/Technical_Bulletins/Zinc\%20Air\%20Tech\%20Bulletin.pdf [65] Alsema E, Patyk A. Investigation on storage technologies for intermittent renewable energies: evaluation and recommended R\&D strategy. WP5 Final reportenvironmental issues. INVESTIRE-Network, 2003.

[66] Buchmann I. Is Lithium-ion the Ideal Battery? 2012 [cited 201221 June]. Available from: http://batteryuniversity.com/learn/article/is_lithium_ion_the_ideal_battery. [67] Perrin M, Simonin L, Baldit P, Mahler P, Ruddell A. Investigation on storage technologies for intermittent renewable energies: evaluation and recommended R\&D strategy. Mapping of centres of excellence. INVESTIRE-Network, 2003. [68] Hewitt NJ. Built Environment Energy Storage - The Challenges for Heat Pumps and Air-Conditioning. World Renewable Energy Congress XI Abu Dhabi, UAE2010. [69] U.S. Department of the Interior. Mineral commodity summaries 2012. United States: U.S. Department of the Interior, 2012.

[70] National Hydropower Association. Challenges and opportunities for new pumped storage development. 2012 [cited 201310 April]. Available from:

http://www.hydro.org/wpcontent/uploads/2012/07/NHA_PumpedStorage_071212b1.pdf [71] Inage S. Prospects for large scale energy storage in decarbonised grids. International Energy Agency Working Paper. 2009 [cited 201310 April]. Available 
from:

http://www.iea.org/publications/freepublications/publication/energy_storage.pdf [72] SMA. Smart home. Germany: SMA, 2012.

[73] Electric Advisory Committee. Bottling electricity: storage as a strategic tool for managing variability and capacity concerns in the modern grid. USA: Electric Advisory Committee, 2008.

[74] Sander M, Gehrig R, Neumann H, Jordan T. LIQHYSMES storage unit - Hybrid energy storage concept combining liquefied hydrogen with superconducting magnetic energy storage. International Journal of Hydrogen energy 2012(37):1430014306.

[75] Research Reports International. Enhancing the Value of Wind Power with Energy Storage. Colorado: Research Reports International, 2008.

[76] European Commission. DG ENER Working Paper: The future role and challenges of energy storage. 2013 [cited 201310 April]. Available from:

http://ec.europa.eu/energy/infrastructure/doc/energystorage/2013/energy_storage.pdf

[77] Baker J, Collinson A. Electrical energy storage at the turn of the millenium. Power Eng J. 1999;6:107-12.

[78] Hawaiian Electric Company. Energy storage 2012 [cited 201220 August].

Available from:

http://www.heco.com/portal/site/heco/menuitem.508576f78baa14340b4c0610c510 b1ca/?vgnextoid=94600420af0db110VgnVCM1000005c011bacRCRD\&vgnextchannel $=a b 020420 a f 0 \mathrm{db} 110 \mathrm{VgnVCM} 1000005 \mathrm{c011}$ bacRCRD\&vgnextfmt=default\&vgnextrefre sh $=1 \&$ level $=0 \& c t=$ article.

[79] Das T, McCalley J. Educational chapter: compressed energy storage 2012 [cited 201221 August]. Available from:

http://home.eng.iastate.edu/ jdm/wind/Compressed Air Energy

Storage_Chapter_TRISHNA DAS.pdf.

[80] Murray J. French firm unveils "game-changing" hydrogen storage system 2010 [cited 201221 August]. Available from:

http://www.businessgreen.com/bg/news/1805351/french-firm-unveils-gamechanging-hydrogen-storage.

[81] Lazarewicz M, Judson J. Performance of first 20MW commercial flywheel frequency regulation plant 2011 [cited 201221 August]. Available from: http://www.beaconpower.com/files/Beacon_Power_presentation_ESA 6_7_11_FINAL.pdf.

[82] Kaldellis JK, Zafirakis D, Kavadias K. Techno-economic comparison of energy storage systems for island autonomous electrical networks. Renewable \& Sustainable Energy Reviews. 2009 Feb;13(2):378-92. PubMed PMID: WOS:000262905500005. [83] Reed C. Flywheel energy storage: energy storage via rotational inertia 2010 [cited 201221 August]. Available from: 
http://mragheb.com/NPRE\%20498ES\%20Energy\%20Storage\%20Systems/Christopher \%20Reed\%20Flywheel\%20Energy\%20Storage.pdf

[84] Van der Burgt J. Transportable, flexible, grid-connected storage 2012 [cited 2012 21 August]. Available from: http://smartgridsherpa.com/blog/transportable-flexiblegrid-connected-storage.

[85] Okimoto A, editor NaS battery application. DERBI (Development of Renewable Energy Resources in Building and Industry) 2009 International Conference; 2009 June 11-13; Perpignan, France.

[86] http://www.azom.com. Superconducting Magnetic Energy Storage (SMES) Systems 2001 [cited 201221 August]. Available from: http://www.azom.com/article.aspx?ArticleID=1123 -_How_fast_can.

[87] Lieurance D, Kimball F, Rix C. Modular transportable superconducting magnetic energy systems 1995 [cited 201219 August]. Available from:

http://ntrs.nasa.gov/archive/nasa/casi.ntrs.nasa.gov/19960000275_1996900275.pdf. [88] Buchmann I. Can the lead-acid battery compete in modern times? 2012 [25 September 2012]. Available from:

http://batteryuniversity.com/learn/article/can_the_lead_acid_battery_compete_in_ modern_times.

[89] Saft. Nickel-Cadmium (Ni-Cd) - SBLE, SBM, SBH - Block battery construction 2007 [cited 201222 August]. Available from:

http://www.saftbatteries.com/Produit_SBLE_SBM_SBH_Block_battery_construc tion_293_38/Language/en-US/Default.aspx

[90] Evans B. EE382C embedded software systems - battery technology 2000 [cited 201221 August]. Available from:

http://users.ece.utexas.edu/ bevans/courses/ee382c/lectures/batteries.html. [91] Kazempour SJ, Moghaddam MP, Haghifam MR, Yousefi GR. Electric energy storage systems in a market-based economy: Comparison of emerging and traditional technologies. Renewable Energy. 2009 Dec;34(12):2630-9. PubMed PMID: WOS:000269711300014.

[92] Palmer L. Zebra battery 2008 [cited 201222 August]. Available from: http://www.solartaxi.com/technology/zebra-battery/.

[93] Sauer D, Kleimaier M, Glaunsinger W. Relevance of energy storage in future distribution networks with high penetration of renewable energy sources. 20th International Conference on Electricity Distribution; 8-11 June; Prague2009.

[94] Tassin N. Investigation on storage technologies for intermittent renewable energies: evaluation and recommended R\&D strategy. INVESTIRE-Network, 2006.

[95] Tong W. Wind power generation and wind turbine design. Southampton, UK: WIT Press; 2010. 725 p.

[96] McKenna P. Startup promises a revolutionary grid battery 2012 [cited 201220 August]. Available from: http://www.technologyreview.com/news/426535/startuppromises-a-revolutionary-grid-battery/. 
[97] Steve's Digicams. Zinc-air battery packs 2012 [cited 201223 July]. Available from: http://www.steves-digicams.com/accessories/batteries/other-chargers/zinc-airbattery-packs.html - b.

[98] Worth B, Perujo A, Douglas K, Tassin N, Brüsewitz M. Investigation on storage technologies for intermittent renewable energies: evaluation and recommended R\&D strategy. WPST9-Metal-air systems. INVESTIRE-Network, 2008.

[99] Willer B. Investigation on storage technologies for intermittent renewable energies: evaluation and recommended R\&D strategy. WPST3-Supercaps. INVESTIRENetwork, 2003.

[100] Crompton T. Battery reference book. 3 ed. Oxford, UK: Reed Educational and Professional Publishing; 2000.

[101] Braithwaite J, Auxer W. Sodium Beta batteries. Sandia National Laboratories; 1993. [cited 201310 April]. Available from:

http://www.sandia.gov/ess/publications/SAND1993-0047j.pdf [102] Kim J, Li G, Lu X, Lemmon J, Sprenkle V, Cui J, Kirby B, Canfield N, Reed D, Meinhardt K, Bonnett J, Coffey G, Mansonav J, Yang G. Intermediate temperature: planar Na-Metal Halide batteries. Pacific Northwest National Laboratory. DOE EES Program Peer Review and Update Meeting; 26-28 Sept; Washington DC 2012. [cited 201310 April]. Available from: http://energy.gov/sites/prod/files/ESS\%202012\%20Peer\%20Review\%20\%20Intermediate\%20Temperature\%20Planar\%20NaMetal\%20Halide\%20Batteries\%20-\%20Jin\%20Kim,\%20PNNL.pdf 


\section{References for Table 2}

\begin{tabular}{|c|c|c|c|c|c|c|c|c|c|c|c|c|c|c|c|c|c|c|c|c|c|c|c|c|c|c|c|}
\hline \multirow{2}{*}{\multicolumn{2}{|c|}{ PHS }} & $\begin{array}{l}\text { Power } \\
\text { rating } \\
\text { MW }\end{array}$ & $\begin{array}{l}\text { Energy } \\
\text { rating } \\
\text { kWh }\end{array}$ & \begin{tabular}{|c|} 
Specific \\
power \\
W/kg \\
\end{tabular} & $\begin{array}{l}\text { Specific } \\
\text { energy } \\
\mathrm{Wh} / \mathrm{kg}\end{array}$ & $\begin{array}{l}\text { Power } \\
\text { density } \\
\mathrm{kw} / \mathrm{m}^{3}\end{array}$ & \begin{tabular}{|l|} 
Energy \\
density \\
$\mathrm{kWh} / \mathrm{m}^{3}$ \\
\end{tabular} & \begin{tabular}{|c|}
$\begin{array}{c}\text { Round- } \\
\text { trip eff. } \\
\%\end{array}$ \\
\end{tabular} & \begin{tabular}{|l|l} 
Critical \\
voltage \\
V
\end{tabular} & $\begin{array}{c}\text { Discharge } \\
\text { time }\end{array}$ & $\begin{array}{c}\text { Response } \\
\text { time }\end{array}$ & $\begin{array}{l}\text { Lifetime } \\
\text { (years) }\end{array}$ & $\begin{array}{l}\text { Lifetime } \\
\text { (cycles) }\end{array}$ & \begin{tabular}{c|} 
Operating \\
temp. \\
${ }^{\circ} \mathrm{C}$
\end{tabular} & \begin{tabular}{|c|} 
Self- \\
discharge \\
$\% /$ day \\
\end{tabular} & \begin{tabular}{c|} 
Spatial \\
requirement \\
$\mathrm{m}^{2} / \mathrm{kWh}$
\end{tabular} & \begin{tabular}{|c|}
$\begin{array}{c}\text { Recharge } \\
\text { time }\end{array}$ \\
\end{tabular} & \begin{tabular}{|c|} 
Inv. power \\
cost \\
$€ / \mathrm{kW}$ \\
\end{tabular} & \begin{tabular}{|c|}
$\begin{array}{c}\text { Inv. energy } \\
\text { cost } \\
\boldsymbol{E} / \mathrm{kWh}\end{array}$ \\
\end{tabular} & \begin{tabular}{|c|} 
Com- \\
mercial \\
use since \\
\end{tabular} & $\begin{array}{l}\text { Technical } \\
\text { maturity }\end{array}$ & $\begin{array}{c}\text { Environ. } \\
\text { impact }\end{array}$ & $\begin{array}{c}\text { Recycla- } \\
\text { bility }\end{array}$ & $\begin{array}{c}\text { Mainte- } \\
\text { nance }\end{array}$ & $\begin{array}{c}\text { Memory } \\
\text { effect }\end{array}$ & $\begin{array}{c}\text { Transpor- } \\
\text { tability }\end{array}$ & \begin{tabular}{|l} 
Cumuli \\
en. den \\
$\mathrm{MJ} / \mathrm{k}^{\prime}$
\end{tabular} \\
\hline & & (10) & (42) & Not appl. & $(10,42)$ & (26) & (26) & $(11,26)$ & \begin{tabular}{|c|} 
Not \\
appl.
\end{tabular} & $(10,26)$ & $(10,32,42)($ & $(10,11,42)$ & (32) & assumption & $(10,42)$ & (53) & (11) & $(10,42)$ & (10) & $(38,77)$ & $(3,26,53)$ & (42) & Not appl. ( & $(38,42)$ & $N / A$ & (42) & $\overline{\mathrm{N} / t}$ \\
\hline \multicolumn{2}{|r|}{ CAES } & (10) & (42) & Not appl. & (10) & (26) & $(3,42)$ & (11) & \begin{tabular}{|l|} 
Not \\
appl.
\end{tabular} & $(10,78)$ & $(10,42)$ & $(10,42)$ & (42) & assumption & (10) & (53) & (79) & $(10,42)$ & (42) & $\mathrm{N} / \mathrm{A}$ & $(3,53)$ & (53) & Not appl. & (38) & N/A & (42) & $\mathrm{N} / t$ \\
\hline \multicolumn{2}{|r|}{ Hydrogen } & (10) & (26) & $(4,10)$ & (26) & (26) & (26) & (11) & \begin{tabular}{|l} 
Not \\
appl.
\end{tabular} & $(10)$ & (53) & $(10)$ & $(10)$ & (11) & $(10)$ & (53) & (53) & (10) & $(10)$ & (80) & $(3,26,53)$ & $(4,53)$ & assumption & (13) & N/A & (51) & 165 \\
\hline \multicolumn{2}{|r|}{ Flywheel } & $(10,42)$ & (42) & $(10,42)$ & (10) & (26) & (26) & (10) & $\begin{array}{r}\text { Not } \\
\text { appl. }\end{array}$ & (10) & \begin{tabular}{|c|}
$(4,10,12$, \\
$32)$
\end{tabular} & $(10,42,51)$ & $(10,42)$ & $(10,42)$ & $(10,11)$ & (53) & (42) & (10) & (10) & (81) & $(3,26)$ & \begin{tabular}{|c|}
$(42,51$, \\
$53)$
\end{tabular} & (65) & $(51,82)$ & (83) & (84) & 165 \\
\hline \multicolumn{2}{|r|}{ SMES } & $(10,42)$ & (42) & (10) & (10) & (26) & (26) & \begin{tabular}{|l|}
$(4,10$, \\
$29,76)$ \\
\end{tabular} & \begin{tabular}{|c} 
Not \\
appl.
\end{tabular} & (10) & $\begin{array}{c}(4,10,32, \\
53)\end{array}$ & $(10,42)$ & $(10,42)$ & $(26,42)$ & (10) & (53) & (86) & (10) & (10) & (42) & $(3,26)$ & (53) & $N / A$ & $(4,42)$ & $N / A$ & (87) & $\mathrm{N} / t$ \\
\hline \multirow{3}{*}{$\mid$} & Pb-acid & (11) & (42) & (10) & $(10,42)$ & (26) & (11) & $(11,26)$ & $(56,58)$ & (10) & $(4,26,53)$ & (10) & (11) & (88) & $(10,82)$ & (53) & (42) & (10) & $(10,11)$ & (42) & $(3,26)$ & (42) & $(11,13,65)(!$ & $(38,82)$ & (66) & (12) & (65 \\
\hline & NiCd & (10) & (42) & (10) & (42) & (26) & (32) & (11) & $(55,58)$ & (10) & $(3,4,26)$ & (10) & (42) & (11) & (10) & (53) & (42) & (10) & (10) & (26) & (26) & (42) & $(42,65)$ & (42) & \begin{tabular}{|c|}
$(3,4$, \\
10,13, \\
$66)$ \\
\end{tabular} & (89) & $(65$ \\
\hline & NiMH & (42) & (42) & $(26,90)$ & (42) & (26) & (32) & (11) & $(55,58)$ & (26) & $(4,26,78)$ & (26) & (42) & $(11,42)$ & (42) & assumption & (42) & (42) & (42) & (26) & (26) & (42) & assumption & (42) & $(10,66)$ & (42) & $\mathrm{N} / t$ \\
\hline \multirow{3}{*}{ 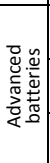 } & Li-ion & (32) & (42) & (32) & $(32,42)$ & (26) & (32) & \begin{tabular}{|c|}
$(11,12,12$ \\
$39)$
\end{tabular} & (56-59) & $(10,32)$ & $(4,26,32) \mid$ & $(5,10,17)$ & $(12,42)$ & (42) & $(10,82)$ & assumption & (32) & (10) & (10) & $(12,42,66)$ & $(3,11)$ & $(13,65)(4$ & $(13,42,65)$ & (42) & \begin{tabular}{|c|}
32,42, \\
$66)$ \\
\end{tabular} & (12) & 165 \\
\hline & NaS & (10) & (42) & (10) & (10) & (26) & $(26,91)$ & (10) & \begin{tabular}{|l|}
$(100$, \\
$101)$ \\
\end{tabular} & $(10,53)$ & $(3,4,26)$ & (11) & (10) & (32) & (10) & (53) & (54) & (10) & (10) & (3) & (3) & $(3,42)$ & $(3,51)$ & $(38,82)$ & (85) & (12) & $\mathrm{N} / t$ \\
\hline & NaNiCl & (10) & (42) & (10) & (10) & (26) & (42) & $(10,13)$ & (102) & (10) & $(4,26,78)$ & (11) & (42) & $(11,42)$ & (10) & assumption & (92) & (10) & (10) & (26) & (93) & N/A & $(42,92)$ & (42) & (92) & (12) & $\mathrm{N} / t$ \\
\hline 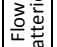 & $\mathrm{ZnBr}$ & (10) & (42) & $(10,42)$ & (42) & (26) & (42) & $(10,39)$ & $(60)$ & (10) & (3) & $(10,11)$ & (10) & $(51,95)$ & $(10,42)$ & (53) & (3) & (10) & (10) & (3) & $(3,10)$ & (42) & (42) & (38) & (51) & $(12,42)$ & $\mathrm{N} / t$ \\
\hline & Zn-air & (48) & (48) & (26) & (50) & (26) & (50) & (87) & $(63,64)$ & (48) & $(4,26,48)$ & (48) & (48) & (97) & $\mathrm{N} / \mathrm{A}$ & assumption & N/A & (48) & $\mathrm{N} / \mathrm{A}$ & (48) & (26) & \begin{tabular}{|l|}
$(4,47$, \\
$48,50)$
\end{tabular} & (13) & (48) & (98) & $(12,47)$ & $(65$ \\
\hline
\end{tabular}

